\title{
A New Contaminant Superhighway? A Review of Sources, Measurement Techniques and Fate of Atmospheric Microplastics
}

Oluchi Mbachu*, Graham Jenkins ${ }^{1}$, Chris Pratt ${ }^{2}$, Prasad Kaparaju ${ }^{1}$

\section{Affiliations}

1 School of Engineering and Built Environment, Griffith University, Nathan Campus, QLD 4111, Australia.

2 School of Environment and Science/ Australian Rivers Institute, Griffith University, Nathan Campus, QLD 4111, Australia.

* Corresponding Author

Email: oluchi.mbachu@griffithuni.edu.au

Conflict-of-interest: Authors declare no conflict of interest

Keywords: Microplastics, atmosphere, microfibres, indoor air, outdoor air, street dust, atmospheric fallout, dust.

\section{List of Abbreviations:}

Polystyrene (PS), Polyethylene (PE), Polyester (PES), Polyamide (PA), Polypropylene (PP), Polyethylene terephthalate (PET), Polyacrylonitrile (PAN), Poly(N-methyl acrylamide) (PAA), Ethylene-vinyl acetate (EVA), Epoxy resin (EP), Alkyd resin (ALK), Poly(ethylene: propylene), Acrylic, Polyurethane (PUR), Polyethyleneimine (PEI), Polyvinyl acetate (PVA), Polycarbonate (PC), hydrogen peroxide $\left(\mathrm{H}_{2} \mathrm{O}_{2}\right)$, polytetrafluoroethylene (PTFE), wet peroxidation (WPO) 


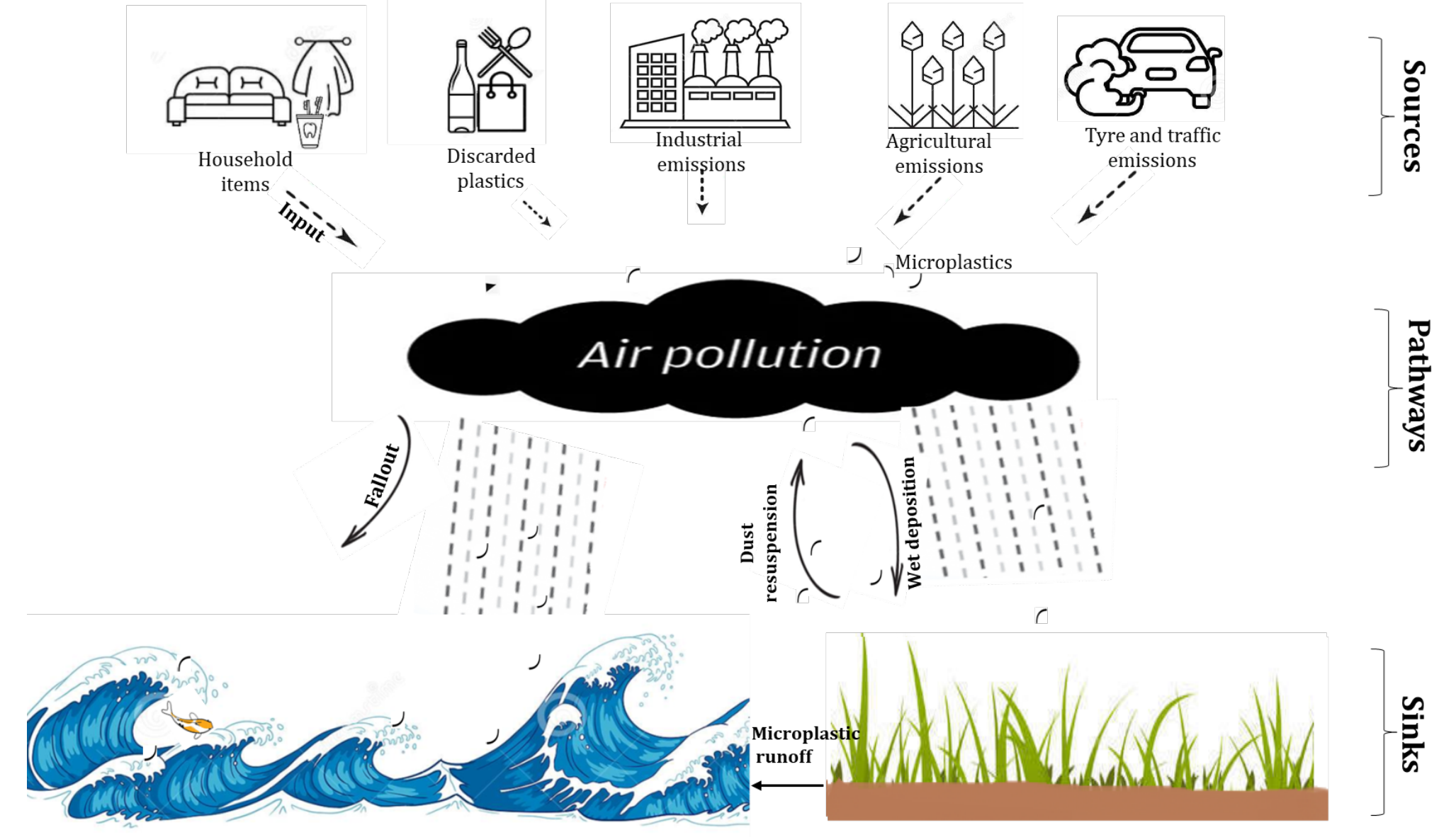

Page $\mid 2$ 


\title{
Highlights
}

- Microplastics are ubiquitous across atmospheric compartments.

- Indoor environments are hotspots of microplastic pollution.

- Fibres dominate atmospheric microplastics morphotypes.

- Most common airborne polymers are PP, PE, PES and PA.

- Microplastics occurs as copolymers in atmospheric compartments.

\begin{abstract}
Microplastic pollution is a significant and growing environmental issue. Recent studies have evaluated the atmosphere as an important pathway of microplastic contamination. Airborne microplastics can be transported long distances and accumulate in various terrestrial and aquatic environmental matrices, where they represent a threat to the biosphere.
\end{abstract}

This review systematically summarizes the existing knowledge on airborne microplastics, including the different sampling and analytical techniques, occurrence and sources. We investigate the different sample collection techniques from street dust to indoor and outdoor air and examined sample preparation, pre-treatment and characterization techniques. We further explored the key factors with respect to their occurrence in the environment such as concentration levels, polymer composition, size distribution, shape and colour characteristics. The sources of airborne microplastics were also summarized. The results show that microplastics are ubiquitous in all atmospheric compartments including street dust, indoor and outdoor air at various concentrations, which is influenced by the community's lifestyle choices, anthropogenic activities, and meteorological conditions.

Various forms of microplastics including spherules, film, fragments, fibres and granules were identified with fibrous microplastics being the most dominant. Additionally, microplastics of 20 different polymers and varying colour characteristic have been reported in studies focusing on airborne microplastic contamination. The size distribution of microplastics varied among the studied air compartments, however, they were mostly distributed towards the smaller size ranges, less than $1 \mathrm{~mm}$.

Our review highlights a need to consider atmospheric pathways in addition to soil and water migration dispersion processes for any holistic assessments of microplastic 
threats to the biosphere. Moreover, standardisation of airborne microplastic sampling methods is needed to optimise the effectiveness of future work in this area.

\section{Introduction}

Research in plastic pollution began when the first synthetic polymer was created, which led to myriad developments in the application and creation of plastic products. This has contributed continuously to the presence of plastic debris in the environment. In the past three decades, the reliance on plastic products has led to an unprecedented upsurge in plastic pollution, with a 3\% annual increase in worldwide plastic production. In 2017, global plastic production reached 348 million tonnes (Plastic Europe, 2018) and it is projected to have a fourfold increase from 311 million tonnes in 2014 to 1.2 billion tonnes by the year 2050 (Ryan, 2015). With the increasing volume in plastic production, the use of plastic materials has gained versatility in everyday life application from household items to personal care products due to its lightweight and form(Andrady, 2011). However problems such as incessant illegal disposal of plastic waste and slow disintegration under environmental conditions have consequently created a new wave of environmental and health concerns. Hence the focus on by-products generated from plastic waste termed "microplastics".

Microplastic (i.e. particles $<5 \mathrm{~mm}$ in diameter) contamination in both terrestrial and aquatic environments is a growing global concern. Microplastic contaminants, originating mostly from the replacement of natural elements with plastic substitutes (Fendall and Sewell, 2009, Napper et al., 2015, Napper and Thompson, 2016, Zitko and Hanlon, 1991) are considered an emerging key source of environmental degradation. For example, polyester production surged from 3.37 million metric tonnes in 1975 to 52.7 million metric tonnes in 2015 as a result of its widespread use in synthetic clothing fibres (Statista, 2019), far surpassing cellulose production. Between the years of 1994 to 2014 , cellulose production worldwide amounted to approximately 5.0 million metric tonnes (Liu et al., 2019c). This material substitution highlights the drivers behind the ubiquity of microplastics in the environment.

The abundance of microplastics in the atmosphere arises from a range of different activities including agricultural processes, indiscriminate plastic waste disposal, domestic activities, wear and tear from tyres and industrial emissions in areas of high anthropogenic activities (Browne et al., 2011, Kole et al., 2017, Jambeck et al., 2015). 
These activities pollute the atmosphere and play a significant role in airborne microplastic levels and environmental degradation. In addition to the concentration levels, the presence of microplastics in the atmosphere represents a significant problem due to its effects on living organisms. A simulation study by Vianello et al. (2019) demonstrated that airborne microplastic contaminants can be inhaled through direct human exposure. In addition, previous studies of Valic and Zuskin (1977) and Pimentel et al. (1975) have highlighted changes in respiratory and ventilatory functions as potential effects with exposure to synthetic fibres. Furthermore, a review of occupational exposure in workers to airborne microplastic reported that microplastics can result in ailments through dust overloads, oxidative stress, and translocation (Prata, 2018). In other words, the buoyancy and size of microplastics in the air mean that they can be readily ingested or inhaled into the human body even at 1.2 meters above ground level, the minimum breathing height of an adult (Dris et al., 2017).

Despite the atmospheric compartment being considered a source and sink for microplastic pollution, most microplastic studies have focused on terrestrial and aquatic environments (Cole et al., 2011, He et al., 2018, Jiang, 2018, Li et al., 2018a, Mai et al., 2018a, Ng et al., 2018, Van Cauwenberghe et al., 2015) with marine microplastic studies having pre-eminence. The presence of microplastic in the atmospheric compartments have negative impacts on terrestrial and aquatic microplastic levels. Through suspension in air and transportation by wind-driven processes between compartments, airborne microplastics may be deposited onto soil and water surfaces where they are incorporated into the soil profile and float on the surface water respectively. Scheurer and Bigalke (2018) suggested atmospheric deposition as a source of microplastic into soils which was attributed to the presence of small microplastic particles in the absence of larger particles. While such research has hinted at atmospheric deposition as one of the main contributors of microplastic inputs, limited research has been undertaken confirming this.

Nonetheless, to date, a few studies have investigated the occurrence of microplastics in the atmosphere including street dust, indoor and outdoor air. Since 2016, only 11 articles in atmospheric microplastic literature have been published as shown in Figure 1. Despite these investigations, until now the quantitative data on the presence of microplastics in the atmosphere, their concentration levels, pollution source, and 
sampling techniques have not been systematically synthesized. Therefore, in recognition of the potential emerging concerns associated with atmospheric microplastics and reports of the pervasiveness airborne microplastic contamination, this review focuses on microplastic contamination in ambient air environments. It is hypothesised that microplastics would be present in all atmospheric compartments, thus, the review of techniques, abundance, composition, and sources of airborne microplastics are explained in this study.

\section{Review Methodology}

A systematic search was conducted in accordance with the preferred reporting items for systematic reviews and meta-analyses (PRISMA) (Moher et al., 2009). The search of the available literature was undertaken for literature published between 1900 and May 2019 using Google Scholar, Scopus, and Web of Knowledge. Based on Keyword terms detailed below, the search was narrowed to identify publications available on atmospheric microplastic studies.

The term microplastic is used here to describe any plastic particle less than or equal to $5 \mathrm{~mm}$ in size including the different morphotypes of fibres, fragments, pellets, foams, spherule, and films. Our search for articles explicitly evaluating microplastic was conducted using search terms "microplastics", "microparticles", "microbeads", "pellets", "nurdles", "microfibres", "plastic fragments", "soil plastic", "urban microliter", "environment particles", "microfilms", "micro-exfoliants", "disintegrated plastics", "disintegrated plastic debris", "minute plastic materials", and "microscopic anthropogenic litter".

The term Atmospheric environment adopted here describes the air surrounding the Earth's surface including interfaces. To identify studies related to microplastics in the air, we used the search terms "indoor environment", "indoor air", "dust", "outdoor environment", "outdoor air", "street dust", "atmospheric fibres", "atmospheric pollutants", "indoor dust", "atmospheric fallout", "suspended air", "settled dust", "deposited dust", “atmospheric deposition”, "atmospheric compartment", "air", "atmosphere-based", "synthetic particles" and "synthetic fibres".

Using the above search terms together with all inclusion and exclusion criteria, a total of eleven original publications were extracted. The searching, screening and selection process adopted in this study which has been derived from PRISMA is summarized with 
the aid of a flow diagram illustrated in Figure 2. To be included in the overview, publications had to show possible sources or pathways that contributed to the levels of atmospheric microplastic pollution. To this, we included studies on street dust since it is recognised as a transition compartment between the atmosphere and terrestrial environment as the atmosphere is a both a source and sink of street dust microplastics. The search excluded grey kinds of literature such as seminars, articles in foreign languages, governmental and non-governmental reports. From the extracted publications, most of the articles were published from 2016 to the present, with $81 \%$ published in the last two years as highlighted in Figure 1.

Data were extracted from the identified publications and separately branched into the different atmospheric compartments of street dust, indoor air, and outdoor air (Table 1). Valid information from each paper was recorded using a Microsoft Excel database including author, year of publication, continent, and country where the research was conducted, the journal name, sampling information, sampling collection and pretreatment methods, extraction procedure, analytical methods, and the recorded findings.

\section{Microplastics Sources}

All the microplastics in the atmosphere originate from anthropogenic activities. The variety of different anthropogenic activities can be classified into either industrial, agricultural or domestic sources. The industrial emissions encompass recycling, fine grinding of plastics, and plastic garbage incineration activities (Abbasi et al., 2017, Abbasi et al., 2019, Dehghani et al., 2017, Dris et al., 2016). Agricultural sources originate from agricultural procedures including the use of plastic mulching (thin polymer films/sheets) and organic fertilizers derived from sewage sludge (Carr et al., 2016, Nizzetto et al., 2016). Microplastics in sewage sludge are retained particles produced from incomplete removal in wastewater treatment plant processes (Bayo et al., 2016, Carr et al., 2016, Li et al., 2018b, Magni et al., 2019), whereas plastic mulches-thin polymer sheets are used in crop cultivation practices to augment or abridge soil properties (Ekebafe et al., 2011). For example, in arid, semi-arid and cold regions of china, plastic film is used to increase soil temperature and reduce soil water evaporation (Changrong et al., 2014). The utilization of plastic mulches for agricultural use has become a significant source of microplastics into the atmosphere(Liu et al., 2018). 
Another source that cannot be ignored is the domestic inputs i.e. sources of microplastics generated using synthetic household items. Nowadays, household items including clothing materials are made from synthetic polymer materials (Liu et al., 2019c, Liu et al., 2019a). However, through mechanical abrasion, wear, and tear, direct exposure to sunlight and household activities such as air-drying of clothes, some of the plastic fragments are emitted into the atmosphere and hence contributes to the increased number of airborne microfibres. Other sources such as tyre and traffic emissions, increase the concentration of microplastic debris into the atmosphere (Abbasi et al., 2017, Kole et al., 2017). Plastic grinding and incineration processes also contribute to majority substantial proportion of airborne microplastic contamination from industrial activities (Dris et al., 2016).

\section{Sampling and Analytical Techniques}

The sampling strategies, extraction procedures and analytical tools used in the studies are listed below in Tables 2-4. Eleven studies investigated the presence of microplastics in the atmosphere, mainly from indoor and outdoor environments. Outdoor and indoor environment samples consist of deposited dust in the form of settled dust on surfaces and suspended dust samples i.e. dust accumulating in space. Outdoor environment samples comprise microplastics generated from sampling sites that are categorized as either street dust, suspended dust, outdoor air or atmospheric fallout to represent the different outdoor compartments. For example, road dust microplastics consist of plastic particles that accumulate on road or street surfaces while suspended microplastic dust particles represent wind-blown microplastics (Akhter and Madany, 1993). On the other hand, indoor environment studies focus on microplastics in enclosed areas such as family homes and offices. Indoor microplastic sampling and analysis are performed mainly to evaluate the potential of human exposure through dust inhalation (Liu et al., 2019a, Vianello et al., 2019) and to have an overview of microplastic contamination in areas occupied by people (Dris et al., 2017). 


\subsection{Sampling}

Although the sampling methodology adopted for airborne microplastics varied between studies, a common objective was to provide a sample that represented the concentration level in the environment. Street dust samples were collected by sweeping a defined street surface area usually adjacent to road curbs using either a metallic pan and wooden brush (Abbasi et al., 2019, Dehghani et al., 2017), or a plastic pan and brush (Abbasi et al., 2017). A potential advantage of the use of metallic pan over plastic pan is that it minimizes possible plastic contamination. Furthermore, Dehghani et al. (2017) suggested the use of wooden brushes made from stems of dried plants for ease of cleaning to obtain all adhered dust particles after sampling. In their study, the authors used a local anti-static wooden brush made from Sorghum bicolour plant species. The major advantages of the pan and brush sample collection methods are the low-cost, ease of sampling and opportunity to perform analysis at a later time (Dehghani et al., 2017, Liu et al., 2019a). Street dust sampling focuses on the mass concentration of microplastic particles in dust samples.

In contrast, atmospheric fallout and suspended dust sampling is performed by means of a sampling device including a funnel equipped with glass bottles (Cai et al., 2017, Stanton et al., 2019, Dris et al., 2016), vacuum/ambient filter sampler (Abbasi et al., 2019, Kaya et al., 2018), or a suspended particulate sampler (Liu et al., 2019c), or a stand-alone filter pump (Dris et al., 2017). Atmospheric fallout and suspended dust collection usually requires drawing air from the atmosphere through an inlet into a collection bottle or onto a filter paper by means of gravity, precipitation or a pump. Most filter paper material utilized includes glass fibre (Liu et al., 2019c), quartz fibre (Dris et al., 2017), polytetrafluoroethylene membrane (PTFE) (Abbasi et al., 2019), or steel filters (Kaya et al., 2018, Vianello et al., 2019).

The glass bottle sampler has been characterized in atmospheric fallout studies and it considers the opening area of the inlet device to account for the sampling surface. This sampling surface is important, to account for all captured samples within the given period usually expressed as the number of particles $/ \mathrm{m}^{2} /$ day. In using a glass bottle device for sampling, particulate matter deposition is mostly dependent on rainfall and gravity. Additionally, where atmospheric fallout or suspended dust are collected by means of a pump or gravitational force, experiments are usually performed at a specific 
altitude above ground level. In many instances, this is done in order to have a representative sample of the atmospheric environment (Liu et al., 2019c) and to avoid disturbance from human activities which may occur during sampling when pieces of equipment are kept on ground level (Abbasi et al., 2019). Liu et al. (2019c) showed that suspended atmospheric microplastics could be easily collected from heights of $1.7 \mathrm{~m}, 33$ $\mathrm{m}, 80 \mathrm{~m}$ on both sunny and cloudy days.

Indoor air sampling was performed using different sampling techniques with respect to the corresponding matrices. Indoor deposited particles were sampled by the pan and brush method from bedrooms and living rooms floors (Liu et al., 2019a) and by vacuum cleaning (Dris et al., 2017). In the case of indoor suspended dust sampling, a filtration device was utilized. Dris et al. (2017) used a stand-alone sampling pump which absorbs dust through a filter paper while Vianello et al. (2019) used a breathing thermal manikin for human breathing rate simulation. The suspended indoor air sampler were placed at different height to enable accurate evaluation of human exposure to microplastics even at heights similar to the average breathing height of an individual $(1.2 \mathrm{~m})$ (Dris et al., 2017).

\subsection{Sample preparation}

Following sample collection, samples were prepared for analysis to provide analytical data on the characteristics and concentration levels of microplastics present in corresponding environmental matrices. This was performed either using a representative (Abbasi et al., 2017, Abbasi et al., 2019, Liu et al., 2019a) or composite sample (Dehghani et al., 2017). The preparation of atmospheric samples consists of several stages: sieving, organic matter digestion, density separation, filtration and airdrying, the purpose of which is to remove extraneous and biogenic materials that could interfere with the identification of microplastics (Abbasi et al., 2017) and also to eliminate any inorganic contaminants with similar composition to the analyte of interest (Oßmann et al., 2018, Schymanski et al., 2018).

Collected deposited atmospheric samples - including dust from indoor and outdoor settings or the street, are usually first air-dried and then sieved to the standard particle size (usually $\leq 5 \mathrm{~mm}$ ). Thus a $5 \mathrm{~mm}$ sieve is frequently used to represent an equivocal sized based definition of microplastics which is known to include plastic particles up to $5 \mathrm{~mm}$ (Arthur et al., 2008). A study by Liu et al. (2019a) was an exception with the 
authors using a $2 \mathrm{~mm}$ sieve. The process of sieving helps to reduce various coarse extraneous and organic material contents such as leaves, strands of hair, stones, and pieces of paper and further allow the analyses of deposited dust and potential microplastics that are within $\leq 5 \mathrm{~mm}$. For atmospheric fallout samples retrieved with the aid of the glass bottle method, the glass bottles were first rinsed with deionised water to recover all adhered particles and then filtered through a filter paper for further analysis. This is because fallout samples scarcely contain organic material sufficient to impede identification.

In the preparation of microplastics from suspended dust collected with the aid of a filtering device, two approaches were used. The most common approach involved the elimination of the conventional sample preparation methods of air-drying, sieving and digestion. Typically, microplastics retained on filter paper was not extracted, rather the retentate on the filter is directly investigated for the presence of microplastics (Cai et al., 2017, Dris et al., 2016). Where direct examination cannot be performed due to constraints such as the roughness of the filter paper surface (Vianello et al., 2019), a onestep sample preparation is conducted. In this process, the contents of each filter paper are washed and dried before further analysis can be conducted. Abbasi et al. (2019) extracted microplastics by washing with deionized water and drying at $80^{\circ} \mathrm{C}$ in a sand bath while Vianello et al. (2019) used an ethanol solution to extract microplastics before drying on a Zinc Selenide (ZnSe) window at $55^{\circ} \mathrm{C}$.

\subsection{Sample pre-treatment}

A wide range of digestion techniques is currently in use for the removal of biogenic materials from different environmental matrices for microplastic analysis. The presence of organic material in environmental matrices interferes with the counting and identification of microplastics (Hidalgo-Ruz et al., 2012a). To prevent this, purification methods such as wet peroxidation (Hurley et al., 2018, Tagg et al., 2017, Sujathan et al., 2017), acid treatment (Avio et al., 2015, Cole et al., 2014, Dehaut et al., 2016), alkaline treatment (Avio et al., 2015, Dehaut et al., 2016, Mintenig et al., 2017), and enzymatic digestion (Cole et al., 2014, Löder et al., 2017, Mintenig et al., 2017) are used. Miller et al. (2017) and Li et al. (2018a) reviewed the different digestion methods that are useful for organic material removal in marine and freshwater samples respectively. In acid and alkaline treatments, microplastic samples are treated with oxidizing $\left(\mathrm{H}_{2} \mathrm{SO}_{4}, \mathrm{HNO}_{3}\right)$ and 
non- oxidizing acids ( $\mathrm{HCl})$ as well as a strong alkaline agents $(\mathrm{NaOH})$ (Claessens et al., 2013, Carr et al., 2016, Cole et al., 2014, Mintenig et al., 2017). A study on acid and alkaline digestion for biological samples showed damage in microplastics with less tolerance and partial digestion leading to presence of organic residues (Cole et al., 2014, Claessens et al., 2013). Damage to the physical properties of plastics commonly encountered in alkaline and acid treatment introduces a bias in results presented for microplastic contamination in the environment. Carr et al. (2016) showed that during acid treatment, some microplastics were observed to melt at $90^{\circ} \mathrm{C}$ above the continuous operating temperature, leading to altered size distribution and morphotype.

Another common yet effective method for organic matter removal is the wet peroxidation (WPO) method. This method involves biogenic material decomposition by an oxidizing agent commonly hydrogen peroxide $\left(\mathrm{H}_{2} \mathrm{O}_{2}\right)$, Fenton's reagents or sodium hypochlorite $(\mathrm{NaClO})$ carried out at a specific temperature for a specific period of time (Sun et al., 2019). Hydrogen peroxide $\left(\mathrm{H}_{2} \mathrm{O}_{2}\right)$ is the most used oxidizing agent for organic material decomposition due to its ability to completely degrade organic matter without significantly changing the physical characteristics. Nuelle et al. (2014) reported a 50\% decomposition rate of organic matter within a seven-day period using $\mathrm{H}_{2} \mathrm{O}_{2}$. Therefore, with the appropriate concentration, digestion temperature, and duration, organic material can be effectively decomposed. As a result different concentrations of $\mathrm{H}_{2} \mathrm{O}_{2}$ for WPO have been used including 30\% v/v (Liebezeit and Dubaish, 2012, Mathalon and Hill, 2014, Nuelle et al., 2014) and 35\% v/v (Mintenig et al., 2017). Alternative digestion techniques suggested for organic matter degradation include enzymatic degradation (Löder et al., 2017) and alcohol (Bayo et al., 2016). However, these methods are rarely used as they are reported to be costly and time-consuming.

In digesting organic matter in atmospheric samples, the WPO method proved efficient and was commonly utilized. However, not all samples undergo an oxidation process, thus organic matter decomposition is performed for samples with organic matter content large enough to cause interference during identification. In the analysis of dust samples from street surfaces, subsamples of between 10-30 $\mathrm{g}$ of dust from the composite bulk samples were treated with $35-100 \mathrm{ml}$ of $30 \% \mathrm{H}_{2} \mathrm{O}_{2}$ to remove organic matter (Abbasi et al., 2017, Abbasi et al., 2019, Dehghani et al., 2017).Consequently,, the addition of $\mathrm{H}_{2} \mathrm{O}_{2}$ promoted the formation of bubbles and was deemed complete when 
bubble formation ceased. In the case of Abbasi et al. (2017) bubble formation lasted seven days while it took eight days in the experiments by Abbasi et al. (2019) and Dehghani et al. (2017). Since the digestion time could take an average of 7 days to digest half of the biogenic content, a viable alternative, Fenton's reagent - a solution of hydrogen peroxide with Iron(II) sulfate $\left(\mathrm{FeSO}_{4}\right)$ catalyst is recommended as an alternative method to breakdown organic matter within a shorter period (Tagg et al., 2017). In the preparation analysis of microplastic from wastewater, Tagg et al. (2017) demonstrated that Fenton's reagent reduced the exposure time to approximately ten minutes.

Following the decomposition, post-digestion samples are vacuum filtered to remove any residual $\mathrm{H}_{2} \mathrm{O}_{2}$ present which is subsequently accompanied by washing with deionized water and drying of samples in a sand bath at the desired temperature. Figure 3 depicts a summary of the sample preparation steps for microplastics analysis. Where inorganic material (mainly sand particles) separation is needed an extraction step is applied. At present only one extraction procedure in environmental matrices has been described (Hidalgo-Ruz et al., 2012b). This approach termed Density separation involves the separation of microplastics and inorganic particles based on their respective densities using a saturated solution. The purpose of the saturated solution is to differentially extract microplastic from the environmental matrices based on differences in density, resulting in floatation of the lighter material and supernatant extraction (Thompson et al., 2004). Thus, a solution with density greater than the required extract (microplastic) is recommended for use.

Common inorganic salt solutions, used in the density separation of atmospheric microplastics include sodium iodide (Abbasi et al., 2017, Abbasi et al., 2019) and zinc chloride (Dehghani et al., 2017, Dris et al., 2017, Kaya et al., 2018, Liu et al., 2019a). Highdensity solutions of zinc chloride and sodium iodide solution give good extraction efficiencies as a result of their ability to produce solutions with densities within the range of $1.6-1.8 \mathrm{~g} / \mathrm{cm}^{3}$, which is an optimum density required for the separation of microplastics from mineral particles (Van Cauwenberghe et al., 2015). Zinc chloride is most commonly used due to its unit cost per volume (Coppock et al., 2017). NaI solution although not commonly used for microplastic extraction, primarily due to its high cost, has been reported to have good recovery efficiencies for high-density microplastics 
from various environmental matrices (Coppock et al., 2017).

\subsection{Identification and quantification}

The analysis of microplastics in the atmosphere is a challenge, and although no standard technique has been introduced for their identification, several analytical methods for atmospheric microplastics have been utilized based on their characteristics. Of the wide range of analytical techniques employed for microplastic identification, techniques based on physical and chemical properties are frequently applied (Zhang et al., 2019). A comparison of these analytical methods is shown in Table 3.

\section{Physical characterization techniques}

As shown in Table 2, one of the most common ways of identifying microplastic materials is through their physical characteristics. This generally involves identifying microplastics based on physical properties such as elasticity, hardness, color, shininess, and structure, which are identified in conjunction with visual or optical microscopy techniques (Hidalgo-Ruz et al., 2012a, McDermid and McMullen, 2004, Mai et al., 2018b). For visual analysis, identification techniques like the naked eye and stereomicroscopy are used (Hidalgo-Ruz et al., 2012a). These techniques allow for the initial identification of suspected microplastic material before further characterization, thereby resulting in fewer amounts of unlikely plastic particles (Stanton et al., 2019). However, the reported overestimation, misidentification and underestimation of microplastic is a disadvantage (Song et al., 2015). Cai et al. (2017) reported an overestimation of natural fibres as synthetic fibres by visual identification. An alternative physical method of identifying microplastics is optical microscopy. Fluorescence microscopy, binocular microscopy and polarized light microscopy (PLM) can be used in the determination of microplastics in street dust samples (Abbasi et al., 2017, Abbasi et al., 2019, Dehghani et al., 2017) each with drawbacks and benefits listed in Table 3. Fluorescence microscopy uses a fluorescence microscope coupled with an ultraviolet filter at different wavelengths to examine microplastics. It identifies microplastics using its inherent fluorescent properties which are sometimes added as colouring materials during plastic production (Christie, 1994). The PLM technique, on the other hand, has found application in microplastic analysis mainly through the analysis of various colours (Abbasi et al., 2017). The embedded microplastics in environmental samples are analysed using a polarizing light emitted when rotated under the PLM. Microplastics are then identified 
by the colour produced under rotation. The advantage of this technique is its inexpensive and fast detection method (Abbasi et al., 2017). After the detection of microplastics, the identified microplastics are quantified to determine their abundance in the sampled environmental matrix. Counting of the identified microplastics is performed using Binocular microscopy technique with up to x200 magnification based on their physical properties including mostly their size and shape (Abbasi et al., 2017, Abbasi et al., 2019, Dehghani et al., 2017).

Generally, physical characterization methods are used as a prerequisite for chemical analytical methods (Liu et al., 2019c). This is because microplastics extracted from various environmental matrixes may contain different materials such as paper, wood, and vegetation which exhibit similar characteristics as microplastics (Dekiff et al., 2014). Thus, to avoid over-, mis- and underestimation of microplastic particle, chemical analysis based on particle composition is required (Rios Mendoza and Balcer, 2019).

\section{Chemical characterization techniques}

Characterizing microplastics based on their chemical composition is an important step that differentiates plastic from other particles. Fourier-transform infrared (FTIR) spectroscopy micro-FTIR spectroscopy (Cai et al., 2017, Dris et al., 2017, Dris et al., 2016, Liu et al., 2019a, Liu et al., 2019c), attenuated total reflectance (ATR) -FTIR spectroscopy (Dris et al., 2017, Dris et al., 2016, Kaya et al., 2018, Stanton et al., 2019) \& focal plane array (FPA)-FT-IR spectroscopy (Vianello et al., 2019) and scanning electron microscopy (SEM)(Abbasi et al., 2017, Abbasi et al., 2019, Dehghani et al., 2017) techniques have been widely used to identify plastic types in atmospheric samples.

SEM involves detecting microplastics based on the morphological characteristic and elemental composition of plastics (Eerkes-Medrano et al., 2015). Morphological characteristics are obtained through surface topography analysis where samples to be analysed are placed on a cylindrical SEM stub for analysis. A major advantage of the SEM technique is the knowledge of the degradation patterns (grooves, flakes, pits, adhering particles and fractures) of microplastics collected from the atmosphere (EerkesMedrano et al., 2015). The unique degradation patterns indicate the type of weathering and the origin of the identified microplastics. Degradation patterns such as pit and groove as well as linear fractures are attributed to mechanical degradation and the action of wind respectively (Abbasi et al., 2019, Cai et al., 2017). In contrast to SEM, 
which uses surface morphology and elemental composition to identify microplastics, FT-IR spectroscopic methods uses the chemical composition of plastic particles based on exposure to infrared radiation at different wavelengths and a reference spectra library to characterize microplastics (Mai et al., 2018b, Renner et al., 2019).

\section{Occurrence of microplastics in the atmosphere}

The substitution of natural materials with plastic alternatives have made microplastic occurrence in the atmosphere ubiquitous. Street or road dust, indoor and outdoor air have been reported to be contaminated by airborne microplastics. A detailed occurrence of microplastics in the atmosphere is summarized in Tables 4-6.

\subsection{Microplastic concentrations in street dust}

Street dust is the settled atmospheric particulate matter which accumulates on surfaces especially on road or street surfaces adjoining curbs. Only a few reports on the microplastic content of street dust have been published, with all of them being conducted in Iran (Abbasi et al., 2017, Abbasi et al., 2019, Dehghani et al., 2017). These reports showed the presence of microplastics in all street dust samples with variances in location, weight of dust sampled and number of samples. The quantitative values of the microplastic contamination in street dust extracted from the published literature are given in Table 4. Herein, data were standardized to particles per 10-grams of dust (particles/10g dust) to facilitate comparison between studies.

From the three cities in Iran, the concentration range of microplastics in street dust were reported to be within 28 to 1658 particles/10g dust. The mean concentration was 600 particles/10g dust in Asaluyeh county (Abbasi et al., 2019), 744.80 particles/10g dry dust in Bushehr City (Abbasi et al., 2017) and 115 particles/10g dry dust (theoretical average) in the central district of Tehran (Dehghani et al., 2017).

It was also observed that concentration of microplastics in street dust varied in location with level of development and economic activities. Two comparison studies of urban and industrial areas showed that microplastic concentrations are higher in industrial areas than those in residential areas. For example, Abbasi et al. (2019) found that microplastic concentrations were 950 times higher in industrial areas than urban areas. Similarly the study of Abbasi et al. (2017) showed that urban sites contained 7.9 times less microplastic amount than industrial areas. The higher concentration of microplastics from industrial zones demonstrates that areas surrounding high levels of 
activities contribute significant amounts of microplastic particles in street dust, except in cases where housekeeping measures are implemented This was the case within the central district of Tehran, an industrial hub, with over 7000 industrial units where nightly sweeping operations are conducted to remove debris including plastic debris.(Dehghani et al., 2017). Low microplastic levels was observed in its street dust, and even the lowest amongst studies.

\subsection{Microplastic concentrations in outdoor environments}

In outdoor environments, microplastic studies were quantified either as atmospheric fallout or suspended dust. In total, eight studies conducted investigations in the outdoor environment; three studies in atmospheric fallout (Cai et al., 2017, Dris et al., 2016, Stanton et al., 2019), four studies in suspended dust (Abbasi et al., 2019, Kaya et al., 2018, Dris et al., 2017, Liu et al., 2019c) and one in outdoor deposited dust (Liu et al., 2019a).

Microplastic in atmospheric fallouts was measured and expressed based on the rate of settling, with reported concentrations reports varying from 0 to 355 particles $/ \mathrm{m}^{2} /$ day (Table 5). Dris et al. (2016) studied microplastic in atmospheric fallout in France over two monitoring periods; six months and one year. The concentrations during the monitoring periods averaged $110 \pm 96$ particles $/ \mathrm{m}^{2} /$ day and $53 \pm 38$ particles $/ \mathrm{m}^{2} /$ day respectively with abundance ranging between 2 to 355 particles $/ \mathrm{m}^{2} /$ day. Similarly, Cai et al. (2017) investigated microfibre presence in atmospheric fallout from three sites in Dongguan city, China and reported the occurrence of non-fibrous microplastics and fibres within the range of 175 to 313 particles $/ \mathrm{m}^{2} /$ day. However, identified microplastic particles ranged from 23 to 47 particles $/ \mathrm{m}^{2} /$ day with an average concentration of $36 \pm$ 7 particles $/ \mathrm{m}^{2} /$ day. Additionally, Stanton et al. (2019) reported the presence of natural and extruded fibres in 84 out of 93 atmospheric samples. and a highest mean concentration of 2.90 fibres $/ \mathrm{m}^{2} /$ day for extruded fibre levels.

In studies on microplastics in suspended air, concentrations ranged from 0 to 4.18 particles per cubic meter (n/m $\left.\mathrm{m}^{3}\right)$. Liu et al. (2019c) reported on suspended atmospheric microplastics at different altitudes, with concentration levels ranging from 0 to 4.18 $\mathrm{n} / \mathrm{m}^{3}$ (median, $0.93 \mathrm{n} / \mathrm{m}^{3}$ ). Dris et al. (2017) investigated outdoor air concentrations across seasons, with results ranging from 0.3 to 1.5 fibres $/ \mathrm{m}^{3}$ and a median value of 0.9 fibres $/ \mathrm{m}^{3}$. Finally, Abbasi et al. (2019) characterized microplastic in suspended dust by 
measuring particle levels in industrial and urban areas. The study reported an abundance of microplastic particles in the range between 0.3 to 1.1 particles $/ \mathrm{m}^{3}$ when normalized for atmospheric particulate matter that have a diameter of less than $2.5 \mu \mathrm{m}$. Comparing the three studies, suspended air sampled in Iran and Paris showed similar minimum and maximum microplastic amounts, but the highest contamination level was found in China ( $4.18 \mathrm{n} / \mathrm{m}^{3}$ ). Despite the variance in range, Paris and Shanghai exhibited similar yet slightly different median values (Table 5). The variance in concentration levels is likely related to population densities. Iran (Asaluyeh County) has a population of 73,958 individuals (2016 census) which is approximately 28 and 327 times less than the populace of Paris and Shanghai respectively. This could lead to the generation and abundance of fewer microplastics in suspended air.

In addition to suspended dust, microplastic has also been detected in outdoor deposited dust. Published quantitative values are given in Table 5. Investigating the concentrations of microplastic particles in outdoor dust, Liu et al. (2019a) reported that outdoor dust microplastic abundance ranged between 7-431 fibres/mg dust for fibrous particles and 0-100 particle/mg dust for granular particles. This result is substantially different from that recorded in street dust which can be explained by the difference in sampling locations. First, high concentrations of microplastics in deposited street dust have been related to areas of high industrial activity (Abbasi et al., 2017, Abbasi et al., 2019). Another reason is that outdoor dust locations in this study comprised areas with little to no dust particles such as windowsills and open-air balconies from an urban family apartment, hence the low concentrations.

Microplastic distribution in outdoor environments is influenced by, meteorological conditions, population density, and gross domestic product. Rainfall is a significant factor contributing to microplastic fallout variability. Dris et al. (2016) showed that microplastics abundance was higher during wet weather or high cumulated rainfall periods than in dry periods. The study further reported concentrations ranging from 11-355 particles $/ \mathrm{m}^{2} /$ day during rainy periods (2-5 mm/day) while in dry periods (0$0.2 \mathrm{~mm} /$ day) a lower concentration between 2-34 particles $/ \mathrm{m}^{2} /$ day in atmospheric fallout. Similarly, Dris et al. (2017) reported five times more fibre deposition during precipitation events. Also, the exclusion of non-fibrous microplastics and the use of large pore size or mesh openings could contribute to reduced microplastic concentrations 
during identification process. Stanton et al. (2019) recorded the lowest measured microplastic concentration range of $0-31.58$ fibres $/ \mathrm{m}^{2} /$ day probably due to the large sieve used $(38 \mu \mathrm{m})$.

Population density and industrialization levels also play an important role in the concentration of outdoor microplastics. Abbasi et al. (2017) observed higher amounts of microplastic numbers in the northern part of Bushehr city than in the southern part. Likewise, Dris et al. (2016) reported more fibre abundance in urban sites than in suburban sites. The higher concentrations in the northern and urban sites can be explained by the difference in microplastic pollution load due to the excessive number of shops, level of industrial activities and density of the surrounding populations compared to their counterparts.

Along with the aforementioned factors, spatial distribution such as space and altitude also influence microplastic numbers in the outdoor environments (Kaya et al., 2018, Liu et al., 2019c). Liu et al. (2019c) reported a decrease in microplastic concentration horizontally from areas of human interference towards the seashore. They observed the lowest concentration near the seaside in Shanghai, which indicates the dilution by ocean air and decreasing human activity influence. Furthermore, concentrations of microplastic were observed to be more abundant at $1.7 \mathrm{~m}$ AGL compared to $80 \mathrm{~m} \mathrm{AGL}$, highlighting the importance of microplastic density and buoyancy in settling and accumulation processes.

\subsection{Microplastic concentrations in indoor environments}

The three studies on indoor air evaluated either concentration in settled dust, dust fall or both. Therefore, comparisons are difficult due to various sampling differences. Consequently, large variations exist between reported indoor settled and suspended dust distributions.

The indoor concentration of microplastics in dustfall was typically in the range of 0.459.4 fibres $/ \mathrm{m}^{3}$ (Dris et al., 2017, Vianello et al., 2019). Vianello et al. (2019) using a breathing thermal manikin, found an average number of $9.3 \pm 5.8$ microplastics inhaled by the manikin per unit volume of $16.8 \mathrm{~m}^{3}$ and a range of 1.7 to 1.62 particles $/ \mathrm{m}^{3}$. Also Dris et al. (2017) reported an average median concentration of 5.4 fibres $/ \mathrm{m}^{3}$; corresponding to a range of between 0.4-59.4 fibre $/ \mathrm{m}^{3}$. For indoor settled dust, Dris et al. (2017) reported a microfibre abundance of 190-670 fibres/mg and 17-620 
fibres/mg from three and fifteen dust samples respectively. Additionally granule information collected showed that, on average, 6-184 particle/mg were present in indoor settled dust (Liu et al., 2019a). All three studies showed that the occurrence of microplastics in indoor environments originate mostly from indoor plastic materials. Thus, indicating indoor environments as hotspots for microplastic emissions.

The variations in indoor microplastic concentrations could be related to various factors such as cleaning habits, building materials, furniture and household activities (Dris et al., 2017, Vianello et al., 2019). For example, Dris et al. (2017) observed higher numbers of microplastics in one apartment compared to another apartment. due to differences in household materials, such as exposed indoor clothes drying lines and the presence of carpeted floors. Similarly, Vianello et al. (2019) reported significant variations in the inter-microplastics concentration between three studied apartments.as a result of differences in building materials, activities and cleaning procedures.

Despite the inter-matrix differences of airborne microplastics, microplastic concentrations were shown to be significantly higher in indoor air samples than outdoor air samples. There are various reasons which explain the higher indoor microplastic content. First, the indoor environment is categorized by vast types of plastic materials acquired to enhance livability and suit lifestyle of occupants. These materials which may include synthetic carpets, furniture, synthetic clothing and plastic toys, through abrasion and handling disintegrate and emits microplastic particles into the atmosphere. Various studies have shown shedding of synthetic materials as a source of microplastic (fibre) emission in the environment (Belzagui et al., 2019, Pirc et al., 2016, Sillanpaa and Sainio, 2017, Yang et al., 2019, Zambrano et al., 2019). Another factor driving higher microplastic concentrations indoors compared with outdoors may be the enclosed nature of indoor spaces. Enclosed spaces are often poorly ventilated with high human activities and plastic sources which reduces air dilution needed to lower the concentration of indoor microplastics. In this review indoor microplastic were samples from bedrooms, living rooms and offices.

In contrast the microplastic content in outdoor environments appears to be much lower, with differences noted between street dust, atmospheric fallout and suspended dust. The main difference between each compartment was in the microplastic morphology as shown in Tables 4-6. Street dust was characterized mostly by nonfibrous microplastics 
while atmospheric fallout and suspended dust are often dominated by fibrous microplastic particles. Despite the difference in shapes, the presence of microplastic in the overall atmosphere was dominated by fibres (Figure 4). However, this abundance was not subjected to synthetic fibres alone, as fibrous natural, artificial and copolymers were also reported (Cai et al., 2017, Dris et al., 2017, Dris et al., 2016, Stanton et al., 2019, Vianello et al., 2019) which demonstrate potential for a wider definition of what constitutes a microplastic.

\section{Overview of microplastics characteristics}

Microplastics undergo various physical transformations before being suspended or deposited in the corresponding atmospheric compartments. Because of their significantly different densities and buoyancy in the atmosphere, microplastics are mainly categorised by their (1) shape; (2) colour; (3) polymer composition and (4) size. These properties play a significant role in characterising the presence of microplastics in the environment and determining the outcomes of their presence including the effect on both human and environmental health.

\subsection{Shape}

So far, atmospheric microplastics have been reported as fibres, granules, fragment, films, spherule, foam and pellets (Abbasi et al., 2017, Abbasi et al., 2019, Cai et al., 2017, Dehghani et al., 2017, Dris et al., 2017, Dris et al., 2016, Kaya et al., 2018, Liu et al., 2019a, Liu et al., 2019c, Stanton et al., 2019, Vianello et al., 2019). The most common morphotype was reported to be fibres, accounting for about $44 \%$ of the total synthetic particles as shown in Figure 4. The presence of the various morphotypes is dependent on the atmospheric compartment in which they are discovered and the anthropogenic activities within the surrounding environment. In street dust, the composition of particle by shape varied between studies. An example is in a study conducted by Abbasi et al. (2017) where fibre was reported to be the dominant shape with comprising $75.87 \%$ of observed morphotypes. Another example is in the studies of Dehghani et al. (2017) and Abbasi et al. (2019) were granule (65.9\%) and spherule (74\%) dominated respectively. The variance in forms reported in the three studies is indicative of the surrounding area around sampling locations. For example, Abbasi et al. (2017) conducted their study in Bushehr city in Iran, a fishing hub where the emission of fibres from ropes and nets used in this region contaminates the environment, hence the 
predominance of fibres. However, in outdoor and indoor air studies, microplastic abundance was dominated by fibrous forms (Cai et al., 2017, Dris et al., 2017, Dris et al., 2016, Kaya et al., 2018, Liu et al., 2019a, Liu et al., 2019c, Stanton et al., 2019, Vianello et al., 2019). According to Liu et al. (2019c) fibres including fiber fragments comprised $67 \%$ of the total microplastics particles observed while fragment and granules comprised of 30\% and 3\% respectively. Similarly, Abbasi et al. (2019) reported the dominance of microplastics by fibres with only three fragment and three film plastics identified in suspended dust. The higher abundance of fibres may be explained by their low mass to surface area ratio, which makes it easier to be resuspended due to wind action. This also influences their and susceptibility to long-range transport (Abbasi et al., 2019).

In addition to the different atmospheric compartments, it was also established through the synthesis of selected publications that the type of shape found varies with development (urbanization and industrialization) and altitude. Abbasi et al. (2019) showed that industrial areas consist of more film, fragment and spherical particles whereas urban areas were dominated by fibrous particles. The difference in distribution may be associated with the large amount of synthetic materials in residential areas which can be released through shedding from synthetic textiles (Almroth et al., 2018, Belzagui et al., 2019, Yang et al., 2019). Also as altitude increases, the number of fragment and granules shaped particles decreases (Liu et al., 2019c). This happens for two reasons; density and gravity. Fragments and granules have higher densities than fibres (Free et al., 2014) and as altitude increases, air pressure drops, therefore, offering less resistance to the, falling motion of denser particles.

\subsection{Colour}

The characteristic of colour is the most common visual feature that aids in the identification of microplastics in all environmental matrices (Hidalgo-Ruz et al., 2012a). Colour characterization is important as it sometimes gives an indication microplastic origin (Peters et al., 2017) and extent of environmental exposure, especially for particles affected by photo degradation (Cole et al., 2011). In addition, various colour modifications are added in the form of pigments or dyes during plastic production for aesthetic appeal (Abrams et al., 2001). The extent of microplastic particles identification based on colour depends mostly on the type of analytical technique used, and the 
observer conducting the visual identification. Regarding analytical techniques, optical methods use a light source which emits energy at different wavelengths and the colour is characterized by the visible spectrum. However, the resulting spectrum is always a perception of the observer which can lead to misidentification of the colour scheme especially when similar. For example, due to the similarities of red and pink most studies group them as the same colour (Abbasi et al., 2017, Abbasi et al., 2019).

Six of the eleven reviewed studies reported the colour distribution of microplastic in the atmosphere (Tables 4-6). These combined studies show that eleven different colours occur for plastics detected in the ambient atmosphere (Abbasi et al., 2017, Abbasi et al., 2019, Dehghani et al., 2017, Kaya et al., 2018, Liu et al., 2019c, Stanton et al., 2019). Among the different studies, colour distribution of microplastics in dust samples showed a wide spectrum across studies with; black/grey, white/transparent, red/pink, blue/green, yellow/orange, and brown. However their abundance differed with location and type of human activity. Abbasi et al. (2017) and Dehghani et al. (2017) reported found the colours of red/pink (56.21\%) and black dominated commercial and industrial areas respectively.

In addition to the different atmospheric matrices, level of development may substantially influence the colour distribution of microplastics. Industrial areas were dominated with a higher proportion of black microplastics than urban areas (Abbasi et al., 2019). Furthermore, the microplastic morphology have been identified to play an important role in colour distribution. Abbasi et al. (2019)study has shown colour differences between film, fiber, spherules and fragments. Among the white/transparent colour identified, film microplastics comprised of the highest abundance with $90 \%$ while fiber and spherule (66\%) and fragment (45\%) exhibited the lowest abundance.

\subsection{Size distributions}

Size distribution is another indicator used in microplastic classification. One goal of size reporting in atmospheric studies is to determine their inhalation and ingestion tendencies on the human population (Gasperi et al., 2018). Size classification of microplastics is commonly reported in terms of particle diameter or length because of their irregular shapes. Liu et al. (2019c) found a transversal difference in microfibres with about $29 \%$ of the fibres identified exhibiting a round shape with a diameter ranging from $14-19 \mu \mathrm{m}$ in size, while the remaining were flat with lengths between $10-37 \mu \mathrm{m}$ 
in size. A comparison of the reported microplastic sizes from different atmospheric compartments is given in Tables 4-6.

Abbasi et al. (2019) and Dehghani et al. (2017) characterized the microplastic size distribution in street dust samples. The microplastic samples were separated into the following size fractions: $\mathrm{L} \leq 100 \mu \mathrm{m}, 100<\mathrm{L} \leq 250 \mu \mathrm{m} ; 250<\mathrm{L} \leq 500 \mu \mathrm{m} ; 500<\mathrm{L} \leq 1000 \mu \mathrm{m}$; $1000<\mathrm{L} \leq 5000 \mu \mathrm{m}$. The size fraction between 250 to $500 \mu \mathrm{m}$ accounted for the highest number of microplastics (33.7\%) in the study conducted by (Dehghani et al., 2017) while particles within the 100-250 $\mu \mathrm{m}$ range had the highest percentage in the study by Abbasi et al. (2019). The two studies showed a decrease in microplastic number as size range increased, indicating that larger particles rarely existed in street dust.

Indoor microplastics showed a different size distribution from outdoor microplastics. A range of 4650-4850 $\mu \mathrm{m}$ was reported for dust fall samples whereas particles no longer than $3250 \mu \mathrm{m}$ were observed in indoor air (Dris et al., 2017). The size distribution of microplastic between the different compartments was associated with their density and buoyancy in the air as larger particles tend to deposit more rapidly. Only one study reported on the size distribution of microplastics in suspended air. By the use of an image J software program for the determination of the sizes of microplastics, Liu et al. (2019c) showed that suspended microplastic ranged in size from 23.07-9555 $\mu \mathrm{m}$ with an average size of $582.2 \mu \mathrm{m}$.

Cai et al. (2017) and Dris et al. (2016) determined the size distribution of microplastics in atmospheric fallout. Three sampling sites from Dongguan China were investigated and the size distribution showed the highest percentage of microplastic within the 200$700 \mu \mathrm{m}$ range, and a variation of sizes from less than $200 \mu \mathrm{m}$ to greater than $4200 \mu \mathrm{m}$ (Cai et al., 2017). Similarly, Dris et al. (2016) reported predominant microfibre distribution in the range of 200-600 $\mu \mathrm{m}$ with fewer fibres less than $200 \mu \mathrm{m}$. The lower percentage of microplastics in the smallest size range was reported by Dris et al. (2016) and Dehghani et al. (2017). Results from both studies can be explained by the size detection limit which restricted detection to particles $<50 \mu \mathrm{m}$.

Like shape characteristic, size distribution was found to vary with increasing altitude in dust samples. The relationship between size and altitude is shown in the study conducted by Liu et al. (2019c) where the largest size ranging between 23.07-9955 $\mu \mathrm{m}$ (mean: $597.5 \mu \mathrm{m}$ ) was detected at $1.7 \mathrm{~m}$ above ground level and the smallest size with 
a range of 25.07-504.6 $\mu \mathrm{m}$ (mean: $176.2 \mu \mathrm{m}$ ) was observed at the middle sampling point (33 m). The author reported that the larger sizes (mean:830 $\mu \mathrm{m}$ ) occurred at the highest sampling point (80 m) where sizes ranged between 47.70-2230 $\mu \mathrm{m}$. This was considerably higher than the mean value recorded at the middle altitude. Incomplete plastic waste incineration through chimneys was associated with the larger sizer distribution.

\subsection{Polymer Composition}

In the context of our microplastic definition, we have only considered polymers of purely synthetic origin. Copolymers made from a mixture of natural and synthetic materials, as well as artificial materials made from the transformation of natural polymers have not been considered in this review. However natural polymers were widely distributed across many environments and details of the particles/fibres identified in them, derived from published literature, are given in Table 8. Herein, polymer composition refers to only pure synthetic particle of petrochemical origin as well as their co-polymers.

No analysis on the composition of polymers was reported in the reviewed literature in the street dust samples. This can be attributed to the identification methods employed which was solely based on physical characteristics. The 20 most common polymers found in atmospheric microplastics are polystyrene, polyethylene, polyester, polyamide, polypropylene, polyethylene terephthalate, polyacrylonitrile, poly (n-methyl acrylamide), ethylene-vinyl acetate, epoxy resin, alkyd resin, poly (ethylene: propylene), acrylic, polyurethane, polyethyleneimine, polyvinyl acetate, polycarbonate, phenoxy resin, and ethylene propylene diene monomer. Generally, the percent abundance of synthetic particles detected in the atmosphere was low when compared to natural or artificial particles (mostly fibres made from natural sources e.g. rayon) as shown in Table 8. According to research by Dris et al. (2017), indoor environments had higher amounts of natural fibres (67\%) than synthetic fibres (33\%). Similarly, in atmospheric fallout, Dris et al. (2016) reported that $50 \%$ and $21 \%$ of analysed fibres were of natural and artificial origin respectively while synthetic material comprised $17 \%$ of the total abundance.

Besides the presence of natural and artificial particles, studies have continuously detected the presence of co-polymers in the atmosphere (Dris et al., 2017, Liu et al., 
2019a, Dris et al., 2016, Kaya et al., 2018). For example, Dris et al. (2017) detected a mixture of polyamide and cotton as well as copolymers of polypropylene and polyethylene. The presence of co-polymers is mainly the result of modification operations in plastic products needed to meet specific consumer demands. In two indoor studies, polyester was found to be the most frequent polymer (Liu et al., 2019a, Vianello et al., 2019). This, however, is in contrary to the indoor study conducted by Dris et al. (2017) where polypropylene was reported the dominant synthetic polymer. The occurrence of PES and PP polymers stems from their extensive use in textile fabric for indoor furnishings (carpet and furniture) as well as clothing materials. Therefore, the variance in study could be a result of occupants' lifestyle choices. Studies by Dris et al. (2016) and Liu et al. (2019c) found Polyethylene-terephthalate to be the most dominant polymer in suspended air while Cai et al. (2017) identified polyethylene (14\%) as the highest occurring synthetic polymer in atmospheric fallout.

While different polymer compositions of fibrous materials may provide insight into atmospheric pollution Fig 5 depicts the relative abundance of purely synthetic polymers in the atmosphere. Polyamide, polyethylene, polyester and polypropylene were the most common polymers. The representative relative abundance corresponds to the reported production rates. Polyethylene, polyester and polypropylene which were similarly abundant in atmospheric samples are widely used in the plastic industry. Synthetic plastic production is dominated by PP with 65 million metric tonnes produced in 2015 (The Conversation, 2018). PP is commonly used in household food packaging and automotive industry (PlasticsEurope, 2018). PE and PES (sometimes classified as PET) accounts for 64 million metric tonnes and 33 million metric tonnes of the total plastic productions respectively (The Conversation, 2018). PE polymers are used in reusable bags, agricultural films and containers while PES is mostly used in the textile industry (PlasticsEurope, 2018). The highest abundance of nylon can be explained by the fact that this polymer is not restricted in its use for textile making (Vianello et al., 2019). Nowadays, a variety of items including car tyres, ropes and consumer goods are made from nylon, hence its occurrence in outdoor and indoor environments.

\section{Effects of airborne microplastics on biota}

This review highlights the ubiquity of microplastic contamination across all atmospheric compartments with slight variances in their physiochemical properties. As 
concentrations of airborne microplastics increases, potential harm in biota is likely to increase through exposure routes. The effects of microplastics on biota have been investigated based on their physicochemical properties such as size, shape, presence of additives or sorbed chemical contaminants (Cole et al., 2013, Jemec et al., 2016, Rainieri et al., 2018, Von Moos et al., 2012). It is well known that due to their size, the impacts of microplastics on biota differ. For example, large microplastics are known to cause entanglements (Bergmann et al., 2015) while smaller size range can be taken up biota.(Bellas et al., 2016, Jemec et al., 2016, Neves et al., 2015) A comparison of the size distribution from different air compartments revealed significantly larger microplastic particle size distribution in indoor than outdoor air environments The smaller size distributions of outdoor microplastics indicates that these materials can be easily inhaled or respired in to the human body. This has implication for human health where the human body is known to be susceptible to diseases. Similar to size distribution, a range of different colours of microplastics were found. The results show that most plastic products contain a wide variety of additives in the form of pigments and dyes to enhance their visual aesthetic. However, due to their similarities with animal feed, coloured microplastics can be ingested by fauna (Costa et al., 2010), causing potential adverse health effects. Thus, underlying the importance of microplastic colour characterization in microplastic occurrence studies.

Our review further gives an insight into the potential negative environmental health impacts of atmospheric microplastics. A problem associated with airborne microplastic contamination is the potential of deposition onto soil and water body surfaces. In most ecosystems the increase in microplastics amounts leads to increased concentration level of microplastics and thus negatively impact upon the respective fauna and flora. Soil particles either capture or serve as a reservoir for airborne microplastics and studies have shown atmospheric deposition either through wind or precipitation, as a source of microplastics (Liu et al., 2018). Furthermore, microplastics that are not adhered to the soil matrix may be conveyed into surface water via runoff (Liu et al., 2019b) or leached into groundwater, contaminating both surface and groundwater bodies. On the other hand, during high rainfall events, microplastics in the air can be directly deposited into downstream water bodies, resulting in increased microplastic pollution in receiving catchments and potential exposure to marine species. 
Since there is no way of precisely removing airborne microplastic contamination, another potential problem associated with atmospheric microplastic exposure, is the possibility of ingestion, inhalation and bioaccumulation by living organisms. Microplastics can be inhaled or ingested by range of terrestrial living organisms from earthworms to humans and can result in different health effects. Based on simulation, up to 272 microplastic particles can be inhaled by humans over 24 hours in indoor environments (Vianello et al., 2019). Adults are estimated to consume between 107736 particles per year under normal conditions whereas children ingest three times more; approximately 644-3223 particles per year (Dehghani et al., 2017). Although the health effects of microplastics in living organisms especially humans have not been fully understood, different investigations have hinted on potential threats to the human health. Exposure studies have shown that through inhalation or ingestion, synthetic material are causative agents of pulmonary diseases in humans (Pimentel et al., 1975, Prata, 2018, Valic and Zuskin, 1977). Additionally, in mesofauna, once ingested, these tiny particles affect their physiology and wellbeing, decreasing mobility, growth, reproduction and fitness (Ju et al., 2019, Kim and An, 2019, Lu et al., 2018). These microplastic particles can also bioaccumulate in the body of the soil organisms and alter their gut microbial communities causing tissue damages and affect immune system responses (Jin et al., 2019, Rodriguez-Seijo et al., 2017, Wang et al., 2019, Zhu et al., 2018).

Airborne microplastics can also be vectors for other toxic pollutants accumulating in the air. In industrial environments where microplastics and other pollutants coexist, there is additional potential for indirectly introducing other toxic and harmful contaminants into ecosystems. The potential for microplastics to contribute to the contaminant loading in environmental matrices and organisms has been widely discussed (Brennecke et al., 2016, Teuten et al., 2007, Hodson et al., 2017, Koelmans et al., 2016, Viršek et al., 2017). Due to their sorption capacity and the potential introduction of associated pollutants in the atmosphere, such as organic pollutants (Hart et al., 1993), atmospherically-derived microplastics present a significant potential threat to the biosphere. Hence the need for a continued research to understand airborne microplastics pollution, its occurrence and impacts. 


\section{Conclusion and perspectives}

Atmospheric compartments have become hotspots for microplastic pollution. In recent years, some studies have categorized the atmosphere as a source and sink of microplastics into the environment. This review has provided a systematic overview of microplastics in atmospheric environments, through its focus on the sampling methods, extraction and identification techniques, occurrence and potential sources. Sampling and identification methods differ significantly among the reviewed inter and intra compartments which presents difficulties for comparison. The two most widely adopted techniques to characterize microplastics in corresponding air matrices are Fouriertransform infrared (FTIR) spectroscopy and scanning electron microscopy (SEM). Microplastics were detected in street dust, indoor and outdoor environments with reported indoor concentrations higher than outdoor concentrations. Regardless of the atmospheric matrices, polyamide, polyethylene, polyester and polypropylene were the most common polymers. with fibrous microplastics accounting for the largest fraction of the identified shapes. Furthermore, microplastics were detected in varying sizes, with reported street dust size distribution varying from $<100-5000 \mu \mathrm{m}$, indoor microplastic size in the range of $\leq 3250-4850$ and outdoor sizes between 2-9555 $\mu \mathrm{m}$. Based on the findings of this review, the current definition of microplastics limits the identification of what constitutes a microplastic both in size classification and polymer composition. We therefore suggest a size range limit and broader definition to include plastic particle consisting of two or more polymers.

Despite the existing knowledge of atmospheric microplastics, some knowledge gaps need to be addressed for better understanding and characterization of microplastics. Most plastic particles reported, occur as a mixture of natural or artificially generated polymers, which presents a problem in defining the chemical composition of what constitutes a microplastic particle. For example, can copolymers of natural and synthetic origin be categorized as a microplastic? As microplastics have been shown to be present in all atmospheric compartments, more research is required on their potential impacts, such as the permissible limit for microplastic ingestion and the allowable concentration of microplastics discharge from major sources into the atmosphere. Current studies of microplastics in the atmosphere relate mainly to their abundance and size distributions. Future studies should include physical characteristics to improve the understanding of 
the properties of microplastics and allow comparison of results between atmospheric compartments. This includes establishing a standardized method for sampling, extraction, identification and result reporting, which are lacking and consequently may not represent the real threat of microplastics to biota.

\section{Acknowledgments:}

The author thanks Griffith University for its GUIPR and GUPR scholarships. 


\section{References}

ABBASI, S., KESHAVARZI, B., MOORE, F., DELSHAB, H., SOLTANI, N. \& SOROOSHIAN, A. 2017. Investigation of microrubbers, microplastics and heavy metals in street dust: a study in Bushehr city, Iran. Environmental earth sciences, 76, 798.

ABBASI, S., KESHAVARZI, B., MOORE, F., TURNER, A., KELLY, F. J., DOMINGUEZ, A. O. \& JAAFARZADEH, N. 2019. Distribution and potential health impacts of microplastics and microrubbers in air and street dusts from Asaluyeh County, Iran. Environmental Pollution, 244, 153-164.

ABRAMS, R., ALI, M., DENTON, P., IGUALADA, J., GROEN, M. \& GSCHWIND, E. 2001. Colouring plastics: fundamentals and trends. Plastics, Additives and Compounding, 3, 18-25.

AKHTER, M. S. \& MADANY, I. M. 1993. Heavy metals in street and house dust in Bahrain. Water, Air, and Soil Pollution, 66, 111-119.

ALMROTH, B. M. C., ÅSTRÖM, L., ROSLUND, S., PETERSSON, H., JOHANSSON, M. \& PERSSON, N.-K. 2018. Quantifying shedding of synthetic fibres from textiles; a source of microplastics released into the environment. Environmental Science and Pollution Research, 25, 1191-1199.

ANDRADY, A. L. 2011. Microplastics in the marine environment. Marine pollution bulletin, 62, 1596-1605.

ARTHUR, C., BAKER, J. \& BAMFORD, H. International research workshop on the occurrence, effects, and fate of microplastic marine debris. Conference Proceedings. Sept, 2008. 9-11.

AVIO, C. G., GORBI, S. \& REGOLI, F. 2015. Experimental development of a new protocol for extraction and characterization of microplastics in fish tissues: first observations in commercial species from Adriatic Sea. Marine environmental research, 111, 1826.

BAYO, J., OLMOS, S., LÓPEZ-CASTELLANOS, J. \& ALCOLEA, A. 2016. Microplastics and microfibres in the sludge of a municipal wastewater treatment plant. International Journal of Sustainable Development and Planning, 11, 812-821.

BELLAS, J., MARTÍNEZ-ARMENTAL, J., MARTÍNEZ-CÁMARA, A., BESADA, V. \& MARTÍNEZ-GÓMEZ, C. 2016. Ingestion of microplastics by demersal fish from the Spanish Atlantic and Mediterranean coasts. Marine pollution bulletin, 109, 55-60.

BELZAGUI, F., CRESPI, M., ÁlVAREZ, A., GUTIÉRREZ-BOUZÁN, C. \& VILASECA, M. 2019. Microplastics' emissions: Microfibres' detachment from textile garments. Environmental Pollution, 248, 1028-1035.

BERGMANN, M., GUTOW, L. \& KLAGES, M. 2015. Marine anthropogenic litter, Springer.

BRENNECKE, D., DUARTE, B., PAIVA, F., CAÇADOR, I. \& CANNING-CLODE, J. 2016. Microplastics as vector for heavy metal contamination from the marine environment. Estuarine, Coastal and Shelf Science, 178, 189-195.

BROWNE, M. A., CRUMP, P., NIVEN, S. J., TEUTEN, E., TONKIN, A., GALLOWAY, T. \& THOMPSON, R. 2011. Accumulation of microplastic on shorelines woldwide: sources and sinks. Environmental science \& technology, 45, 9175-9179.

CAI, L., WANG, J., PENG, J., TAN, Z., ZHAN, Z., TAN, X. \& CHEN, Q. 2017. Characteristic of microplastics in the atmospheric fallout from Dongguan city, China: preliminary research and first evidence. Environmental Science and Pollution Research, 24, 24928-24935.

CARR, S. A., LIU, J. \& TESORO, A. G. 2016. Transport and fate of microplastic particles in wastewater treatment plants. Water research, 91, 174-182. 
CHANGRONG, Y., WENQING, H. \& NEIL, C. 2014. Plastic-film mulch in Chinese agriculture: Importance and problems. World Agriculture, 4, 32-36.

CHRISTIE, R. M. 1994. Pigments, dyes and fluorescent brightening agents for plastics: An overview. Polymer international, 34, 351-361.

CLAESSENS, M., VAN CAUWENBERGHE, L., VANDEGEHUCHTE, M. B. \& JANSSEN, C. R. 2013. New techniques for the detection of microplastics in sediments and field collected organisms. Marine pollution bulletin, 70, 227-233.

COLE, M., LINDEQUE, P., FILEMAN, E., HALSBAND, C., GOODHEAD, R., MOGER, J. \& GALLOWAY, T. S. 2013. Microplastic ingestion by zooplankton. Environmental science \& technology, 47, 6646-6655.

COLE, M., LINDEQUE, P., HALSBAND, C. \& GALLOWAY, T. S. 2011. Microplastics as contaminants in the marine environment: a review. Marine pollution bulletin, 62, 2588-2597.

COLE, M., WEBB, H., LiNDEQUE, P. K., FILEMAN, E. S., HALSBAND, C. \& GALLOWAY, T. S. 2014. Isolation of microplastics in biota-rich seawater samples and marine organisms. Scientific reports, 4, 4528.

COPPOCK, R. L., COLE, M., LINDEQUE, P. K., QUEIRÓS, A. M. \& GALLOWAY, T. S. 2017. A small-scale, portable method for extracting microplastics from marine sediments. Environmental Pollution, 230, 829-837.

COSTA, M. F., DO SUL, J. A. I., SILVA-CAVAlCANTI, J. S., ARAÚJO, M. C. B., SPENGLER, Â. \& TOURINHO, P. S. 2010. On the importance of size of plastic fragments and pellets on the strandline: a snapshot of a Brazilian beach. Environmental Monitoring and Assessment, 168, 299-304.

DEHAUT, A., CASSONE, A.-L., FRÈRE, L., HERMABESSIERE, L., HIMBER, C., RINNERT, E., RIVIĖRE, G., LAMBERT, C., SOUDANT, P. \& HUVET, A. 2016. Microplastics in seafood: benchmark protocol for their extraction and characterization. Environmental Pollution, 215, 223-233.

DEHGHANI, S., MOORE, F. \& AKHBARIZADEH, R. 2017. Microplastic pollution in deposited urban dust, Tehran metropolis, Iran. Environmental Science and Pollution Research, 24, 20360-20371.

DEKIFF, J. H., REMY, D., KLASMEIER, J. \& FRIES, E. 2014. Occurrence and spatial distribution of microplastics in sediments from Norderney. Environmental Pollution, $186,248-256$.

DRIS, R., GASPERI, J., MIRANDE, C., MANDIN, C., GUERROUACHE, M., LANGLOIS, V. \& TASSIN, B. 2017. A first overview of textile fibres, including microplastics, in indoor and outdoor environments. Environmental pollution, 221, 453-458.

DRIS, R., GASPERI, J., SAAD, M., MIRANDE, C. \& TASSIN, B. 2016. Synthetic fibres in atmospheric fallout: A source of microplastics in the environment? Marine Pollution Bulletin, 104, 290-293.

EERKES-MEDRANO, D., THOMPSON, R. C. \& ALDRIDGE, D. C. 2015. Microplastics in freshwater systems: a review of the emerging threats, identification of knowledge gaps and prioritisation of research needs. Water research, 75, 63-82.

EKEBAFE, L., OGBEIFUN, D. \& OKIEIMEN, F. 2011. Polymer applications in agriculture. Biokemistri, 23.

FENDALL, L. S. \& SEWELL, M. A. 2009. Contributing to marine pollution by washing your face: microplastics in facial cleansers. Marine pollution bulletin, 58, 1225-1228.

FREE, C. M., JENSEN, O. P., MASON, S. A., ERIKSEN, M., WILLIAMSON, N. J. \& BOLDGIV, B. 2014. High-levels of microplastic pollution in a large, remote, mountain lake. Marine pollution bulletin, 85, 156-163. 
GASPERI, J., WRIGHT, S. L., DRIS, R., COLLARD, F., MANDIN, C., GUERROUACHE, M., LANGLOIS, V., KELLY, F. J. \& TASSIN, B. 2018. Microplastics in air: Are we breathing it in? Current Opinion in Environmental Science \& Health, 1, 1-5.

HART, K., TREMP, J., MOLNAR, E. \& GIGER, W. 1993. The occurrence and the fate of organic pollutants in the atmosphere. Water, Air, and Soil Pollution, 68, 91-112.

HE, D., LUO, Y., LU, S., LIU, M., SONG, Y. \& LEI, L. 2018. Microplastics in soils: analytical methods, pollution characteristics and ecological risks. TrAC Trends in Analytical Chemistry.

HIDALGO-RUZ, V., GUTOW, L., THOMPSON, R. C. \& THIEL, M. 2012a. Microplastics in the marine environment: a review of the methods used for identification and quantification. Environmental science \& technology, 46, 3060-3075.

HIDALGO-RUZ, V., GUTOW, L., THOMPSON, R. C. \& THIEL, M. 2012b. Microplastics in the marine environment: A review of the methods used for identification and quantification. Environmental Science and Technology, 46, 3060-3075.

HODSON, M. E., DUFFUS-HODSON, C. A., CLARK, A., PRENDERGAST-MILLER, M. T. \& THORPE, K. L. 2017. Plastic bag derived-microplastics as a vector for metal exposure in terrestrial invertebrates. Environmental Science \& Technology, 51, 47144721.

HURLEY, R. R., LUSHER, A. L., OLSEN, M. \& NIZZETTO, L. 2018. Validation of a method for extracting microplastics from complex, Organic-Rich, Environmental Matrices. Environmental science \& technology, 52, 7409-7417.

JAMBECK, J. R., GEYER, R., WILCOX, C., SIEGLER, T. R., PERRYMAN, M., ANDRADY, A., NARAYAN, R. \& LAW, K. L. 2015. Plastic waste inputs from land into the ocean. Science, 347, 768-771.

JEMEC, A., HORVAT, P., KUNEJ, U., BELE, M. \& KRŽAN, A. 2016. Uptake and effects of microplastic textile fibres on freshwater crustacean Daphnia magna. Environmental pollution, 219, 201-209.

JIANG, J.-Q. 2018. Occurrence of microplastics and its pollution in the environment: A review. Sustainable Production and Consumption, 13, 16-23.

JIN, Y. X., LU, L., TU, W. Q., LUO, T. \& FU, Z. W. 2019. Impacts of polystyrene microplastic on the gut barrier, microbiota and metabolism of mice. Science of the Total Environment, 649, 308-317.

JU, H., ZHU, D. \& QIAO, M. 2019. Effects of polyethylene microplastics on the gut microbial community, reproduction and avoidance behaviors of the soil springtail, Folsomia candida. Environmental Pollution, 247, 890-897.

KAYA, A. T., YURTSEVER, M. \& BAYRAKTAR, S. C. 2018. Ubiquitous exposure to microfiber pollution in the air. European Physical Journal Plus, 133.

KIM, S. W. \& AN, Y.-J. 2019. Soil microplastics inhibit the movement of springtail species. Environment International, 126, 699-706.

KOELMANS, A. A., BAKIR, A., BURTON, G. A. \& JANSSEN, C. R. 2016. Microplastic as a vector for chemicals in the aquatic environment: critical review and modelsupported reinterpretation of empirical studies. Environmental science \& technology, 50, 3315-3326.

KOLE, P. J., LÖHR, A. J., VAN BELLEGHEM, F. G. \& RAGAS, A. M. 2017. Wear and tear of tyres: a stealthy source of microplastics in the environment. International journal of environmental research and public health, 14, 1265.

LI, J., LIU, H. \& CHEN, J. P. 2018a. Microplastics in freshwater systems: A review on occurrence, environmental effects, and methods for microplastics detection. Water Research, 137, 362-374. 
LI, X., CHEN, L., MEI, Q., DONG, B., DAI, X., DING, G. \& ZENG, E. Y. 2018 b. Microplastics in sewage sludge from the wastewater treatment plants in China. Water research, 142, 75-85.

LIEBEZEIT, G. \& DUBAISH, F. 2012. Microplastics in beaches of the East Frisian islands Spiekeroog and Kachelotplate. Bulletin of Environmental Contamination and Toxicology, 89, 213-217.

LIU, C., LI, J., ZHANG, Y., WANG, L., DENG, J., GAO, Y., YU, L., ZHANG, J. \& SUN, H. 2019a. Widespread distribution of PET and PC microplastics in dust in urban China and their estimated human exposure. Environment international, 128, 116-124.

LIU, F., OLESEN, K. B., BORREGAARD, A. R. \& VOLLERTSEN, J. 2019b. Microplastics in urban and highway stormwater retention ponds. Science of the Total Environment, 671, 992-1000.

LIU, K., WANG, X., FANG, T., XU, P., ZHU, L. \& LI, D. 2019c. Source and potential risk assessment of suspended atmospheric microplastics in Shanghai. Science of The Total Environment, 675, 462-471.

LIU, M., LU, S., SONG, Y., LEI, L., HU, J., LV, W., ZHOU, W., CAO, C., SHI, H. \& YANG, X. 2018. Microplastic and mesoplastic pollution in farmland soils in suburbs of Shanghai, China. Environmental pollution, 242, 855-862.

LÖDER, M. G., IMHOF, H. K., LADEHOFF, M., LÖSCHEL, L. A., LORENZ, C., MINTENIG, S., PIEHL, S., PRIMPKE, S., SCHRANK, I. \& LAFORSCH, C. 2017. Enzymatic purification of microplastics in environmental samples. Environmental science \& technology, 51, 14283-14292.

LU, L., WAN, Z., LUO, T., FU, Z. \& JIN, Y. 2018. Polystyrene microplastics induce gut microbiota dysbiosis and hepatic lipid metabolism disorder in mice. Science of The Total Environment, 631-632, 449-458.

MAGNi, S., BINELli, A., PITTURA, L., AVIO, C. G., DELlA TORRE, C., PARENTI, C. C., GORBI, S. \& REGOLI, F. 2019. The fate of microplastics in an Italian Wastewater Treatment Plant. Science of the Total Environment, 652, 602-610.

MAI, L., BAO, L.-J., SHI, L., WONG, C. S. \& ZENG, E. Y. 2018a. A review of methods for measuring microplastics in aquatic environments. Environmental Science and Pollution Research, 25, 11319-11332.

MAI, L., BAO, L. J., SHI, L., WONG, C. S. \& ZENG, E. Y. 2018b. A review of methods for measuring microplastics in aquatic environments. Environmental Science and Pollution Research, 25, 11319-11332.

MATHALON, A. \& HILL, P. 2014. Microplastic fibres in the intertidal ecosystem surrounding Halifax Harbor, Nova Scotia. Marine pollution bulletin, 81, 69-79.

MCDERMID, K. J. \& MCMULLEN, T. L. 2004. Quantitative analysis of small-plastic debris on beaches in the Hawaiian archipelago. Marine pollution bulletin, 48, 790-794.

MILLER, M. E., KROON, F. J. \& MOTTI, C. A. 2017. Recovering microplastics from marine samples: A review of current practices. Marine pollution bulletin, 123, 6-18.

MINTENIG, S., INT-VEEN, I., LÖDER, M. G., PRIMPKE, S. \& GERDTS, G. 2017. Identification of microplastic in effluents of waste water treatment plants using focal plane array-based micro-Fourier-transform infrared imaging. Water research, 108, 365-372.

MOHER, D., LIBERATI, A., TETZLAFF, J. \& ALTMAN, D. G. 2009. Preferred reporting items for systematic reviews and meta-analyses: the PRISMA statement. Annals of internal medicine, 151, 264-269.

NAPPER, I. E., BAKIR, A., ROWLAND, S. J. \& THOMPSON, R. C. 2015. Characterisation, quantity and sorptive properties of microplastics extracted from cosmetics. Marine Pollution Bulletin, 99, 178-185. 
NAPPER, I. E. \& THOMPSON, R. C. 2016. Release of synthetic microplastic plastic fibres from domestic washing machines: effects of fabric type and washing conditions. Marine pollution bulletin, 112, 39-45.

NEVES, D., SOBRAL, P., FERREIRA, J. L. \& PEREIRA, T. 2015. Ingestion of microplastics by commercial fish off the Portuguese coast. Marine pollution bulletin, 101, 119-126.

NG, E.-L., LWANGA, E. H., ELDRIDGE, S. M., JOHNSTON, P., HU, H.-W., GEISSEN, V. \& CHEN, D. 2018. An overview of microplastic and nanoplastic pollution in agroecosystems. Science of the Total Environment, 627, 1377-1388.

NIZZETTO, L., LANGAAS, S. \& FUTTER, M. 2016. Do microplastics spill on to farm soils? Nature, 537, 488-488.

NUELLE, M.-T., DEKIFF, J. H., REMY, D. \& FRIES, E. 2014. A new analytical approach for monitoring microplastics in marine sediments. Environmental Pollution, 184, 161169.

OßMANN, B. E., SARAU, G., HOLTMANNSPÖTTER, H., PISCHETSRIEDER, M., CHRISTIANSEN, S. H. \& DICKE, W. 2018. Small-sized microplastics and pigmented particles in bottled mineral water. Water research, 141, 307-316.

PETERS, C. A., THOMAS, P. A., RIEPER, K. B. \& BRATTON, S. P. 2017. Foraging preferences influence microplastic ingestion by six marine fish species from the Texas Gulf Coast. Marine pollution bulletin, 124, 82-88.

PIMENTEL, J. C., AVILA, R. \& LOURENCO, A. 1975. Respiratory disease caused by synthetic fibres: a new occupational disease. Thorax, 30, 204-219.

PIRC, U., VIDMAR, M., MOZER, A. \& KRZAN, A. 2016. Emissions of microplastic fibres from microfiber fleece during domestic washing. Environmental Science and Pollution Research, 23, 22206-22211.

PLASTIC EUROPE 2018. Plastics- the Facts 2018.

PLASTICSEUROPE. 2018. Plastics - the Facts 2018 [Online]. Available: https://www.plasticseurope.org/application/files/6315/4510/9658/Plastics the facts 2018 AF web.pdf [Accessed].

PRATA, J. C. 2018. Airborne microplastics: consequences to human health? Environmental Pollution, 234, 115-126.

RAINIERI, S., CONLLEDO, N., LARSEN, B. K., GRANBY, K. \& BARRANCO, A. 2018. Combined effects of microplastics and chemical contaminants on the organ toxicity of zebrafish (Danio rerio). Environmental research, 162, 135-143.

RENNER, G., NELLESSEN, A., SCHWIERS, A., WENZEL, M., SCHMIDT, T. C. \& SCHRAM, J. 2019. Data preprocessing \& evaluation used in the microplastics identification process: A critical review \& practical guide. TrAC Trends in Analytical Chemistry, 111, 229-238.

RIOS MENDOZA, L. M. \& BALCER, M. 2019. Microplastics in freshwater environments: A review of quantification assessment. TrAC - Trends in Analytical Chemistry, 113, 402-408.

RODRIGUEZ-SEIJO, A., LOURENÇO, J., ROCHA-SANTOS, T. A. P., DA COSTA, J., DUARTE, A. C., VALA, H. \& PEREIRA, R. 2017. Histopathological and molecular effects of microplastics in Eisenia andrei Bouché. Environmental Pollution, 220, 495503.

RYAN, P. G. 2015. A brief history of marine litter research. Marine anthropogenic litter. Springer, Cham.

SCHEURER, M. \& BIGALKE, M. 2018. Microplastics in Swiss floodplain soils. Environmental science \& technology, 52, 3591-3598. 
SCHYMANSKI, D., GOLDBECK, C., HUMPF, H.-U. \& FÜRST, P. 2018. Analysis of microplastics in water by micro-Raman spectroscopy: release of plastic particles from different packaging into mineral water. Water research, 129, 154-162.

SILLANPAA, M. \& SAINIO, P. 2017. Release of polyester and cotton fibres from textiles in machine washings. Environmental Science and Pollution Research, 24, 19313-19321.

SONG, Y. K., HONG, S. H., JANG, M., HAN, G. M., RANI, M., LEE, J. \& SHIM, W. J. 2015. A comparison of microscopic and spectroscopic identification methods for analysis of microplastics in environmental samples. Marine Pollution Bulletin, 93, 202-209.

STANTON, T., JOHNSON, M., NATHANAIL, P., MACNAUGHTAN, W. \& GOMES, R. L. 2019. Freshwater and airborne textile fibre populations are dominated by 'natural', not microplastic, fibres. Science of The Total Environment, 666, 377-389.

STATISTA. 2019. Production of polyester fibres worldwide from 1975 to 2017 [Online]. Available: https://www.statista.com/statistics/912301/polyester-fiber-productionworldwide/ [Accessed].

SUJATHAN, S., KNIGGENDORF, A.-K., KUMAR, A., ROTH, B., ROSENWINKEL, K.H. \& NOGUEIRA, R. 2017. Heat and bleach: a cost-efficient method for extracting microplastics from return activated sludge. Archives of environmental contamination and toxicology, 73, 641-648.

SUN, J., DAI, X., WANG, Q., VAN LOOSDRECHT, M. C. \& NI, B.-J. 2019. Microplastics in wastewater treatment plants: Detection, occurrence and removal. Water research.

TAGG, A., HARRISON, J. P., JU-NAM, Y., SAPP, M., BRADLEY, E. L., SINCLAIR, C. J. \& OJEDA, J. J. 2017. Fenton's reagent for the rapid and efficient isolation of microplastics from wastewater. Chemical Communications, 53, 372-375.

TEUTEN, E. L., ROWLAND, S. J., GALlOWAY, T. S. \& THOMPSON, R. C. 2007. Potential for plastics to transport hydrophobic contaminants. Environmental science \& technology, 41, 7759-7764.

THE CONVERSATION. 2018. The world of plastics, in numbers [Online]. Available: https://theconversation.com/the-world-of-plastics-in-numbers-100291 [Accessed].

THOMPSON, R. C., OLSEN, Y., MITCHELL, R. P., DAVIS, A., ROWLAND, S. J., JOHN, A. W., MCGONIGLE, D. \& RUSSELL, A. E. 2004. Lost at sea: where is all the plastic? Science, 304, 838-838.

VALIC, F. \& ZUSKIN, E. 1977. Respiratory-function changes in textile workers exposed to synthetic fibres. Archives of Environmental Health: An International Journal, 32, 283-287.

VAN CAUWENBERGHE, L., DEVRIESE, L., GALGANI, F., ROBBENS, J. \& JANSSEN, C. R. 2015. Microplastics in sediments: a review of techniques, occurrence and effects. Marine environmental research, 111, 5-17.

VIANELLO, A., JENSEN, R. L., LIU, L. \& VOLLERTSEN, J. 2019. Simulating human exposure to indoor airborne microplastics using a Breathing Thermal Manikin. Scientific reports, 9, 8670.

VIRŠEK, M. K., LOVŠIN, M. N., KOREN, Š., KRŽAN, A. \& PETERLIN, M. 2017. Microplastics as a vector for the transport of the bacterial fish pathogen species Aeromonas salmonicida. Marine pollution bulletin, 125, 301-309.

VON MOOS, N., BURKHARDT-HOLM, P. \& KÖHLER, A. 2012. Uptake and effects of microplastics on cells and tissue of the blue mussel Mytilus edulis L. after an experimental exposure. Environmental science \& technology, 46, 11327-11335.

WANG, J., COFFIN, S., SUN, C. L., SCHLENK, D. \& GAN, J. 2019. Negligible effects of microplastics on animal fitness and HOC bioaccumulation in earthworm Eisenia fetida in soil. Environmental Pollution, 249, 776-784. 
YANG, L., QIAO, F., LEI, K., LI, H., KANG, Y., CUI, S. \& AN, L. 2019. Microfiber release from different fabrics during washing. Environmental Pollution, 136-143.

ZAMBRANO, M. C., PAWLAK, J. J., DAYSTAR, J., ANKENY, M., CHENG, J. J. \& VENDITTI, R. A. 2019. Microfibres generated from the laundering of cotton, rayon and polyester based fabrics and their aquatic biodegradation. Marine Pollution Bulletin, 394-407.

ZHANG, S., WANG, J., LIU, X., QU, F., WANG, X., WANG, X., LI, Y. \& SUN, Y. 2019. Microplastics in the environment: A review of analytical methods, distribution, and biological effects. TrAC - Trends in Analytical Chemistry, 111, 62-72.

ZHU, D., CHEN, Q.-L., AN, X.-L., YANG, X.-R., CHRISTIE, P., KE, X., WU, L.-H. \& ZHU, Y.-G. 2018. Exposure of soil collembolans to microplastics perturbs their gut microbiota and alters their isotopic composition. Soil Biology and Biochemistry, 116, 302-310.

ZITKO, V. \& HANLON, M. 1991. Another source of pollution by plastics: skin cleaners with plastic scrubbers. Marine Pollution Bulletin, 22, 41-42. 
TABLE 1: Details of the 11 studies examining Microplastics pollution in the atmosphere included in the review

\begin{tabular}{|c|c|c|c|c|c|}
\hline $\mathbf{S} / \mathbf{N}$ & $\begin{array}{l}\text { Atmospheric } \\
\text { compartment }\end{array}$ & Journal & Continent & Country & References \\
\hline 1 & Street dust & $\begin{array}{l}\text { Environmental earth } \\
\text { sciences }\end{array}$ & Asia & Iran & Abbasi et al. (2017) \\
\hline 2 & Atmospheric fallout & $\begin{array}{l}\text { Environmental Science } \\
\text { and Pollution Research }\end{array}$ & Asia & China & Cai et al. (2017) \\
\hline 3 & $\begin{array}{l}\text { Street / road dust } \\
\text { Suspended dust }\end{array}$ & $\begin{array}{c}\text { Environmental } \\
\text { Pollution }\end{array}$ & Asia & Iran & Abbasi et al. (2019) \\
\hline 4 & Street dust & $\begin{array}{l}\text { Environmental Science } \\
\text { and Pollution Research }\end{array}$ & Asia & Iran & Dehghani et al. (2017) \\
\hline 5 & $\begin{array}{l}\text { Indoor environment } \\
\text { Outdoor environment }\end{array}$ & $\begin{array}{c}\text { Environmental } \\
\text { Pollution }\end{array}$ & Europe & France & Dris et al. (2017) \\
\hline 6 & $\begin{array}{l}\text { Atmospheric fallout } \\
\text { Suspended dust }\end{array}$ & $\begin{array}{c}\text { European Physical } \\
\text { Journal Plus }\end{array}$ & Europe & Turkey & Kaya et al. (2018) \\
\hline 7 & Indoor air & Scientific reports & Europe & Denmark & Vianello et al. (2019) \\
\hline
\end{tabular}




\begin{tabular}{|c|c|c|c|c|c|}
\hline 8 & $\begin{array}{l}\text { Indoor dust } \\
\text { Outdoor dust }\end{array}$ & $\begin{array}{l}\text { Environment } \\
\text { international }\end{array}$ & Asia & China & Liu et al. (2019a) \\
\hline 9 & Atmospheric fallout & $\begin{array}{c}\text { Marine Pollution } \\
\text { Bulletin }\end{array}$ & Europe & France & Dris et al. (2016) \\
\hline 10 & Atmospheric fallout & $\begin{array}{l}\text { Science of The Total } \\
\text { Environment }\end{array}$ & Europe & United Kingdom & Stanton et al. (2019) \\
\hline 11 & Suspended dust & $\begin{array}{l}\text { Science of The Total } \\
\text { Environment }\end{array}$ & Asia & China & Liu et al. (2019c) \\
\hline
\end{tabular}


TABLE 2: Summary of the method published for collection, treatment and analytical methods for microplastics

\begin{tabular}{|c|c|c|c|c|c|c|c|c|}
\hline Matrix & $\begin{array}{c}\text { Sample } \\
\text { collection }\end{array}$ & $\begin{array}{c}\text { Criteria } \\
\text { 1: Area }\end{array}$ & $\begin{array}{c}\text { Criteria } \\
\text { 2: } \\
\text { Height }\end{array}$ & $\begin{array}{c}\text { No of } \\
\text { samples }\end{array}$ & Sampling treatment & Technique & $\begin{array}{c}\text { Size } \\
\text { cut- } \\
\text { off } \\
(\mu \mathrm{m})\end{array}$ & Ref \\
\hline Street dust & $\begin{array}{c}\text { Metallic pan } \\
\text { and wooden } \\
\text { brush }\end{array}$ & \# & & 10 & $\begin{array}{l}\text { Pass samples through a } \\
5 \mathrm{~mm} \text { sieve; add } 100 \mathrm{ml} \\
\text { of } \mathrm{H} 202 \text { and filter } \\
\text { through a } 2 \mu \mathrm{m} \text { filter } \\
\text { paper; wash with MilliQ } \\
\text { water. Add } 100 \mathrm{ml} \text { of } \\
\mathrm{ZnCl} 2 \text { for density } \\
\text { separation and filter } \\
\text { through } \mathrm{S} \& \mathrm{~S} 2 \mu \mathrm{m} \text {; air- } \\
\text { dry for } 24 \mathrm{hrs} \\
\end{array}$ & $\begin{array}{c} \\
\text { Binocular } \\
\text { microscope, } \\
\text { Fluorescence } \\
\text { microscopy \& SEM }\end{array}$ & 50 & $\begin{array}{r}\text { (Dehghani } \\
\text { et al., 2017) }\end{array}$ \\
\hline Street dust & $\begin{array}{c}\text { Plastic } \\
\text { dustpan and } \\
\text { brush }\end{array}$ & $\#$ & & 24 & $\begin{array}{l}\text { Pass samples through a } \\
5 \mathrm{~mm} \text { sieve; add } 35 \mathrm{ml} \text { of } \\
\mathrm{H} 202 \text { to digest organic } \\
\text { matter and filter digest } \\
\text { organic matter and filter } \\
\text { through a } 2 \mu \mathrm{m} \text { filter } \\
\text { paper; wash with MilliQ } \\
\text { water. Add } 50 \mathrm{ml} \text { of NaI } \\
\text { for density separation. } \\
\text { Centrifuge to remove } \\
\text { inorganic particles and } \\
\text { filter using S\&S } 2 \mathrm{~mm}\end{array}$ & $\begin{array}{c} \\
\text { Binocular } \\
\text { microscope, } \\
\text { Fluorescence } \\
\text { microscopy \& PLM }\end{array}$ & & $\frac{\text { (Abbasi et }}{\text { al., 2017) }}$ \\
\hline
\end{tabular}




\begin{tabular}{|c|c|c|c|c|c|c|c|c|}
\hline $\begin{array}{l}\text { Atmospheric } \\
\text { fallout }\end{array}$ & $\begin{array}{c}\text { Stainless } \\
\text { funnel } \\
\text { equipped with } \\
\text { glass bottles } \\
(20 \mathrm{~L}) \\
\end{array}$ & & & $\begin{array}{c}24 \\
\text { (site1) } \\
9 \text { (site2) }\end{array}$ & $\begin{array}{l}\text { Rinse with RO water to } \\
\text { recover adhered } \\
\text { particles and filter } \\
\text { through } 1.6 \mu \mathrm{m} \text { quartz } \\
\text { fibre filters }\end{array}$ & $\begin{array}{l}\text { Stereo microscope } \\
\text { \& ATR FT-IR }\end{array}$ & 50 & $\frac{\text { (R. Dris et }}{\text { al., 2016) }}$ \\
\hline $\begin{array}{l}\text { Atmospheric } \\
\text { fallout }\end{array}$ & $\begin{array}{l}\text { Sampling } \\
\text { device } \\
\text { equipped with } \\
\text { glass bottles }\end{array}$ & \# & $x$ & 9 & $\begin{array}{l}\text { Recover adhered } \\
\text { particles on the walls of } \\
\text { the bottle with ultrapure } \\
\text { water and filter through } \\
1.0 \mu \mathrm{m} \text { glass fibre filters; } \\
\text { dry at } 50 \mathrm{oC} \text { for } 48 \mathrm{hrs}\end{array}$ & $\begin{array}{l}\text { Digital microscope, } \\
\text { micro-FT-IR \& SEM }\end{array}$ & & $\frac{\text { (Cai et al. }}{\underline{2017)}}$ \\
\hline $\begin{array}{c}\text { Atmospheric } \\
\text { Fallout }\end{array}$ & $\begin{array}{c}\text { Glass funnel } \\
\text { equipped with } \\
\text { glass bottles } \\
(2.5 \mathrm{~L})\end{array}$ & & $\mathrm{X}$ & 93 & $\begin{array}{l}\text { Extract particles with } \\
\text { distilled water and filter } \\
\text { through a mixed } \\
\text { cellulose filter paper }\end{array}$ & $\begin{array}{c}\text { stereo microscope, } \\
\text { ATR-FT-IR }\end{array}$ & & $\frac{\text { (Stanton et }}{\text { al., 2019) }}$ \\
\hline $\begin{array}{l}\text { Outdoor air } \\
\text { (suspended } \\
\text { and } \\
\text { atmospheric } \\
\text { fallout) }\end{array}$ & $\begin{array}{l}\text { Vacuum filter } \\
\text { sampler }\end{array}$ & & & & $\begin{array}{l}\text { Digest organic } \\
\text { impurities with } \mathrm{H}_{2} \mathrm{O}_{2} \text {; } \\
\text { add } \mathrm{ZnCl} 2 \text { for density } \\
\text { separation; centrifuge } \\
\text { and filter using } 500 \mu \mathrm{m} \\
\text { and } 50 \mu \mathrm{m} \text { for air } \\
\text { samples; } 20 \mu \mathrm{m} \text { for soil } \\
\text { samples }\end{array}$ & $\begin{array}{l}\text { Light microscopy \& } \\
\text { micro-ATR FT-IR }\end{array}$ & & $\frac{\text { (Kaya et al., }}{\underline{2018)}}$ \\
\hline
\end{tabular}




\begin{tabular}{|c|c|c|c|c|c|c|c|}
\hline Street dust & $\begin{array}{l}\text { Metallic pan } \\
\text { and wooden } \\
\text { brush }\end{array}$ & & 15 & $\begin{array}{l}\text { Air-dry for } 7 \text { days and } \\
\text { sieve through } 5 \mathrm{~mm} \\
\text { sieve; dissolve organic } \\
\text { matter with } 50 \mathrm{ml} \mathrm{H}_{2} \mathrm{O}_{2} \text {; } \\
\text { add } 50 \mathrm{ml} \text { of } \mathrm{NaI} \text { for } \\
\text { density separation, } \\
\text { centrifuge and filter } \\
\text { using S\&S paper; air-dry } \\
\text { at room temperature }\end{array}$ & $\begin{array}{c}\text { Fluorescence } \\
\text { microscopy, PLM \& } \\
\text { SEM }\end{array}$ & & $\frac{\text { (Abbasi et }}{\underline{\text { al., 2019) }}}$ \\
\hline $\begin{array}{l}\text { Suspended } \\
\text { dust }\end{array}$ & $\begin{array}{l}\text { Ambient filter } \\
\text { sampler }\end{array}$ & $\mathrm{x}$ & 16 & $\begin{array}{l}\text { Wash filters with } \\
\text { deionized water and dry } \\
\text { in a sand bath at } 80^{\circ} \mathrm{C}\end{array}$ & & & \\
\hline $\begin{array}{l}\text { Suspended } \\
\text { dust }\end{array}$ & $\begin{array}{l}\text { Suspended } \\
\text { particulate } \\
\text { sampler }\end{array}$ & $\mathrm{x}$ & & $\begin{array}{l}\text { Filter air at } 100 \pm 0.1 \\
\mathrm{~L} / \mathrm{min} \text { through } 1.6 \mu \mathrm{m} \\
\text { glass filter paper }\end{array}$ & $\begin{array}{l}\text { Stereo microscope } \\
\text { \& micro-FT-IR }\end{array}$ & & $\frac{(\text { K. Liu et al., }}{\text { 2019) }}$ \\
\hline $\begin{array}{l}\text { Indoor air } \\
\text { Outdoor air }\end{array}$ & $\begin{array}{l}\text { Stand-alone } \\
\text { sampling } \\
\text { pump } \\
\end{array}$ & $\mathrm{x}$ & & & \multirow{2}{*}{$\begin{array}{l}\text { Stereo microscope } \\
\text { \& ATR FT-IR }\end{array}$} & \multirow{2}{*}{50} & \multirow{2}{*}{$\begin{array}{l}\text { (Rachid Dris } \\
\text { et al., 2017) }\end{array}$} \\
\hline $\begin{array}{c}\text { Indoor } \\
\text { settled dust }\end{array}$ & $\begin{array}{l}\text { Vacuum } \\
\text { cleaner }\end{array}$ & & 3 & & & & \\
\hline
\end{tabular}




\begin{tabular}{|c|c|c|c|c|c|c|c|}
\hline & & & & $\begin{array}{l}\text { Sieve dust samples } \\
\text { through } 2.5 \mathrm{~mm} \text { sieve; } \\
\text { add } 50 \mathrm{ml} \text { of } \mathrm{ZnCl}_{2} \text { for } \\
\text { density separation and } \\
\text { filter through } 1.6 \mu \mathrm{m} \\
\text { quartz fibre paper }\end{array}$ & & & \\
\hline $\begin{array}{l}\text { Indoor air } \\
\text { Outdoor air }\end{array}$ & $\begin{array}{l}\text { A pan and hog } \\
\text { bristle brush }\end{array}$ & \# & & $\begin{array}{l}\text { Pass samples through a } \\
\text { 2-mm sieve; add } 50 \mathrm{ml} \text { of } \\
\mathrm{ZnCl}_{2} \text { for density } \\
\text { separation }\end{array}$ & $\begin{array}{l}\text { Light microscopy \& } \\
\text { micro-FT-IR }\end{array}$ & 10 & $\frac{\text { (C. Liu et al. }}{\underline{2019)}}$ \\
\hline Indoor air & $\begin{array}{l}\text { Breathing } \\
\text { thermal } \\
\text { manikin }\end{array}$ & & 9 & $\begin{array}{l}\text { Sonicate filters for } 5 \\
\text { mins in ethanol; drop } \\
\text { liquid containing the } \\
\text { sample in a pre-heated } \\
\text { ZnSe window and dry } \\
\text { ZnSe window for } 48 \mathrm{hrs} \\
\text { at } 55^{\circ} \mathrm{C}\end{array}$ & FPA-micro-FT-IR & 11 & $\frac{\text { (Vianello et }}{\underline{\text { al., 2019) }}}$ \\
\hline
\end{tabular}

microscopy; RO: reverse osmosed; ZnSe: Zinc Selenide 
Table 3: Comparative Techniques for Microplastics Measurement

\begin{tabular}{|c|c|c|c|}
\hline Technique & Advantages & Disadvantages & References \\
\hline Visual identification & $\begin{array}{l}\text { Easier and faster method for } \\
\text { microplastic identification }\end{array}$ & $\begin{array}{l}\text { Leads to mis-, under-, and } \\
\text { overestimation of microplastics } \\
\text { Sensitivity to size } \\
\text { Accuracy is dependent on the } \\
\text { observer } \\
\end{array}$ & $\begin{array}{c}\text { Advantages, } \\
\text { Disadvantages (Cai et } \\
\text { al., 2017) }\end{array}$ \\
\hline Fluorescence microscopy & $\begin{array}{l}\text { Identifies microplastics } \\
\text { without an extensive initial } \\
\text { visual pre-sorting stage }\end{array}$ & $\begin{array}{l}\text { Not all plastics have fluorescence } \\
\text { agents } \\
\text { Potential loss of sample during } \\
\text { preparation step; transfer to glass } \\
\text { slide } \\
\text { Similar material interferences; } \\
\text { leading to an overestimation }\end{array}$ & $\begin{array}{c}\text { Advantages (Abbasi et } \\
\text { al., 2017), } \\
\text { Disadvantages } \\
\text { (Dehghani et al., 2017) }\end{array}$ \\
\hline Polarized light microscopy & Inexpensive and fast method & Other material interferences & $\begin{array}{c}\text { Advantages (Abbasi et } \\
\text { al., 2017) } \\
\text { Disadvantages }\end{array}$ \\
\hline Binocular microscopy & $\begin{array}{l}\text { Utilizes high light reflection } \\
\text { and refraction, particle } \\
\text { shininess and transparency of } \\
\text { glass slides to distinguish } \\
\text { microplastics from foreign } \\
\text { materials such as glass }\end{array}$ & & $\begin{array}{c}\text { Advantages (Dehghani } \\
\text { et al., 2017) }\end{array}$ \\
\hline
\end{tabular}




\begin{tabular}{c|lc}
\hline $\begin{array}{c}\text { Fourier-transform infrared } \\
\text { spectroscopy }\end{array}$ & \multicolumn{1}{c}{$\begin{array}{c}\text { Labor intensive } \\
\text { Limitation of spectra library }\end{array}$} & $\begin{array}{c}\text { Disadvantages(Stanton } \\
\text { et al., 2019) }\end{array}$ \\
\hline Scanning electron microscope & $\begin{array}{l}\text { Detects microplastic particle } \\
\text { accurately }\end{array}$ & $\begin{array}{c}\text { Advantages(Cai et al., } \\
2017, \text { Dehghani et al., }\end{array}$ \\
& $\begin{array}{l}\text { Gives information about } \\
\text { particle experiences }\end{array}$ & 2017) \\
\hline Mass spectroscopy (LC- & Higher sensitivity of detection & Advantages (Liu et al., \\
MS/MS) & & $2019 a)$ \\
\hline
\end{tabular}


TABLE 4: Microplastic Contamination in Street Dust

\begin{tabular}{|c|c|c|c|c|c|c|c|c|c|}
\hline \multirow[t]{2}{*}{ Matrix } & \multirow[t]{2}{*}{ Focus } & \multicolumn{3}{|c|}{ Measured Concentrations } & \multicolumn{5}{|c|}{ Characteristics of MPs } \\
\hline & & Mean & Median & Range & $\begin{array}{c}\text { Total } \\
\text { abundance }\end{array}$ & $\begin{array}{l}\text { Size } \\
(\mu \mathrm{m})\end{array}$ & Shapes & Colours & Ref \\
\hline $\begin{array}{c}\text { Street } \\
\text { dust }\end{array}$ & $\begin{array}{c}\text { Occurrence }+ \\
\text { Characteristics }\end{array}$ & & & $\begin{array}{c}83-605 \\
\text { particles/30g } \\
\text { dry dust }\end{array}$ & 2649 & $\begin{array}{l}<100- \\
5 \mathrm{~mm}\end{array}$ & $\begin{array}{c}\text { fibres, } \\
\text { fragments, } \\
\text { granules, } \\
\text { spherules, } \\
\text { pellets }\end{array}$ & $\begin{array}{l}\text { Blue, red, black, } \\
\text { orange, green, } \\
\text { transparent, } \\
\text { yellow, pink, } \\
\text { brown }\end{array}$ & $\begin{array}{l}\text { (Dehgha } \\
\text { ni et al., } \\
\text { 2017) }\end{array}$ \\
\hline $\begin{array}{l}\text { Street } \\
\text { dust }\end{array}$ & $\begin{array}{c}\text { Occurrence }+ \\
\text { Characteristics }\end{array}$ & $\begin{array}{c}744.80 \\
\text { particles/ } \\
\text { 10g dry } \\
\text { dust }\end{array}$ & $\begin{array}{c}736.50 \\
\text { particles } \\
/ 10 \mathrm{~g} \text { dry } \\
\text { dust }\end{array}$ & $\begin{array}{c}210-1658 \\
\text { particles } / 10 \mathrm{~g} \\
\text { dry dust }\end{array}$ & & & $\begin{array}{c}\text { fibres, } \\
\text { fragments, }\end{array}$ & $\begin{array}{c}\text { Blue/green, } \\
\text { black/grey, } \\
\text { orange/yellow, } \\
\text { white/transpare } \\
\text { nt, red/pink }\end{array}$ & $\begin{array}{l}\text { (Abbasi } \\
\text { et al., } \\
\text { 2017) }\end{array}$ \\
\hline $\begin{array}{c}\text { Street } \\
\text { dust }\end{array}$ & $\begin{array}{c}\text { Occurrence + } \\
\text { Characteristics }\end{array}$ & $\begin{array}{c}900 \\
\text { particles/ } \\
15 \mathrm{~g} \text { dust }\end{array}$ & & $\begin{array}{c}50-1000 \\
\text { particles } / 15 g \\
\text { dust }\end{array}$ & 13132 & & $\begin{array}{l}\text { Spherule, film, } \\
\text { fragments, } \\
\text { fibres }\end{array}$ & $\begin{array}{c}\text { White- } \\
\text { transparent, red- } \\
\text { pink, blue-green, } \\
\text { black/grey }\end{array}$ & $\begin{array}{l}\text { (Abbasi } \\
\text { et al., } \\
\text { 2019) }\end{array}$ \\
\hline
\end{tabular}

PET: polyethylene terephthalate, PE: polyethylene, PES: polyester, PAN: polyacrylonitrile, PAA: poly(N-methyl acrylamide), RY: rayon, EVA: ethylene vinyl acetate, EP: epoxy resin; ALK: alkyd resin; PEP: poly (ethylene: propylene); PC: Polycarbonate, PEI: polyethyleneimine 
TABLE 5: Microplastic Contamination in Outdoor Environments

\begin{tabular}{|c|c|c|c|c|c|c|c|c|c|}
\hline \multirow[t]{2}{*}{ Matrix } & \multirow[t]{2}{*}{ Focus } & \multicolumn{3}{|c|}{ Measured Concentrations } & \multirow[b]{2}{*}{$\begin{array}{l}\text { Size } \\
(\mu \mathrm{m})\end{array}$} & \multicolumn{4}{|c|}{ Characteristics of MPs } \\
\hline & & Mean & median & Range & & Shapes & $\begin{array}{l}\text { Syntheti } \\
\text { c } \\
\text { Polymer } \\
\text { types }\end{array}$ & Colours & Ref \\
\hline Outdoor air & $\begin{array}{c}\text { Occurrence + } \\
\text { Characteristic } \\
\text { s }\end{array}$ & & $\begin{array}{c}0.9 \\
\text { fibres/m } \\
3\end{array}$ & $\begin{array}{c}0.3-1.5 \\
\text { fibres } / \mathrm{m}^{3}\end{array}$ & $\begin{array}{c}< \\
1650\end{array}$ & fibres & $\mathrm{PP}, \mathrm{PA}$ & & $\begin{array}{l}\text { (Dris et } \\
\text { al., } \\
\text { 2017) }\end{array}$ \\
\hline Outdoor air & $\begin{array}{c}\text { Occurrence + } \\
\text { Characteristic } \\
\text { s }\end{array}$ & & & & & $\begin{array}{c}\text { fibres, } \\
\text { fragment } \\
\text { s }\end{array}$ & PES, PA & $\begin{array}{l}\text { dark-blue, } \\
\text { white, } \\
\text { transparen } \\
\text { t, brown }\end{array}$ & $\begin{array}{l}\text { (Kaya et } \\
\text { al., } \\
2018 \text { ) }\end{array}$ \\
\hline $\begin{array}{c}\text { Suspended } \\
\text { dust }\end{array}$ & $\begin{array}{c}\text { Occurrence + } \\
\text { Characteristic } \\
\text { s }\end{array}$ & $\begin{array}{c}1.42 \pm 1.42 \\
\mathrm{n} / \mathrm{m}^{3}\end{array}$ & $\begin{array}{c}0.93 \\
\mathrm{n} / \mathrm{m}^{3}\end{array}$ & $0-4.18 \mathrm{n} / \mathrm{m}^{3}$ & $\begin{array}{c}23.07 \\
- \\
9555\end{array}$ & $\begin{array}{c}\text { fibres, } \\
\text { fragment } \\
\text { s, } \\
\text { granules }\end{array}$ & $\begin{array}{l}\text { PET, PE, } \\
\text { PES, } \\
\text { PAN, } \\
\text { PAA, RY, } \\
\text { EVA, EP, } \\
\text { ALK. }\end{array}$ & $\begin{array}{l}\text { Blue, red, } \\
\text { black, } \\
\text { transparen } \\
\text { t, green, } \\
\text { yellow, } \\
\text { grey, } \\
\text { brown } \\
\end{array}$ & $\begin{array}{l}\text { (Liu et } \\
\text { al., } \\
2019 c \text { ) }\end{array}$ \\
\hline $\begin{array}{l}\text { Atmospheri } \\
\text { c fallout }\end{array}$ & $\begin{array}{c}\text { Occurrence }+ \\
\text { Characteristic } \\
\text { s } \\
\end{array}$ & $\begin{array}{c}110 \pm 96 \\
\text { particles } / \mathrm{m}^{2} / \mathrm{da} \\
\mathrm{y}\end{array}$ & & $\begin{array}{c}2-355 \\
\text { particles } / \mathrm{m}^{2} / \mathrm{da} \\
\mathrm{y} \\
\end{array}$ & $\begin{array}{l}50- \\
600\end{array}$ & & PET, PA & & $\begin{array}{l}\text { (Dris et } \\
\text { al., } \\
2016)\end{array}$ \\
\hline $\begin{array}{l}\text { Atmospheri } \\
\text { c fallout }\end{array}$ & $\begin{array}{c}\text { Occurrence + } \\
\text { Characteristic } \\
\text { s }\end{array}$ & $\begin{array}{c}36 \pm 7 \\
\text { particles } / \mathrm{m}^{2} / \mathrm{da} \\
\mathrm{y}\end{array}$ & & & & $\begin{array}{l}\text { fibres, } \\
\text { fragment } \\
\text { s, foams, } \\
\text { films }\end{array}$ & $\begin{array}{c}\text { PE, PP, } \\
\text { PS }\end{array}$ & & $\begin{array}{l}\text { (Cai et } \\
\text { al., } \\
\text { 2017) }\end{array}$ \\
\hline
\end{tabular}




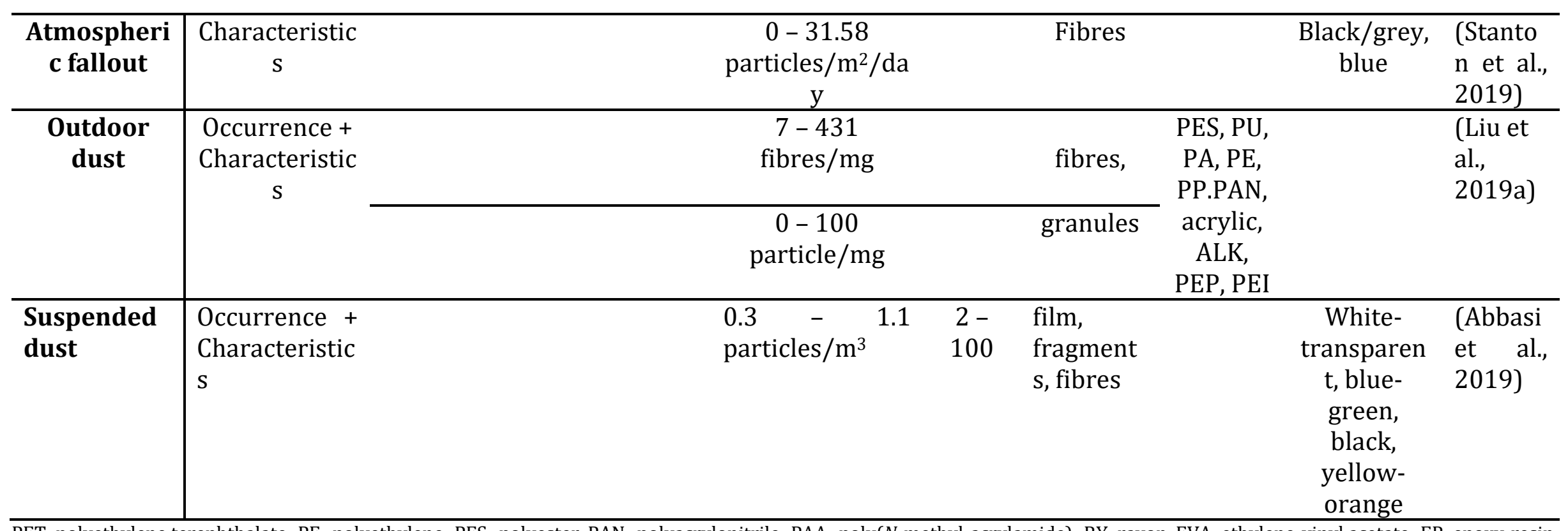

PET: polyethylene terephthalate, PE: polyethylene, PES: polyester, PAN: polyacrylonitrile, PAA: poly( $N$-methyl acrylamide), RY: rayon, EVA: ethylene vinyl acetate, EP: epoxy resin; ALK: alkyd resin; PEP: poly (ethylene: propylene); PC: Polycarbonate, PEI: polyethyleneimine 
TABLE 6: Microplastic Contamination in Indoor Environments.

\begin{tabular}{|c|c|c|c|c|c|c|c|c|}
\hline \multirow[t]{2}{*}{ Matrix } & \multirow[t]{2}{*}{ Focus } & \multicolumn{3}{|c|}{ Measured Concentrations } & \multicolumn{4}{|c|}{ Characteristics of MPs } \\
\hline & & Mean & median & Range & Size $(\mu \mathrm{m})$ & Shapes & $\begin{array}{c}\text { Synthetic Polymer } \\
\text { types }\end{array}$ & Ref \\
\hline \multirow[t]{2}{*}{$\begin{array}{l}\text { Indoor } \\
\text { dust }\end{array}$} & \multirow{2}{*}{$\begin{array}{c}\text { Occurrence }+ \\
\text { Contaminant } \\
\text { load }+ \\
\text { Characteristic } \\
\text { s } \\
\end{array}$} & $\begin{array}{c}342 \\
\text { fibres } / \mathrm{mg}\end{array}$ & & $\begin{array}{c}17-620 \\
\text { fibres } / \mathrm{mg}\end{array}$ & & fibres & \multirow{2}{*}{$\begin{array}{l}\text { PES, PU, PA, PE, PP, } \\
\text { PAN, acrylic, ALK, PEP, } \\
\text { PEI }\end{array}$} & \multirow{2}{*}{$\begin{array}{l}\text { (Liu et } \\
\text { al., } \\
\text { 2019a) }\end{array}$} \\
\hline & & & & $\begin{array}{c}\text { 6- } 184 \\
\text { fibres } / \mathrm{mg}\end{array}$ & & granules & & \\
\hline $\begin{array}{c}\text { Indoor } \\
\text { air }\end{array}$ & \multirow[b]{2}{*}{$\begin{array}{c}\text { Occurrence + } \\
\text { Contaminant } \\
\text { load }+ \\
\text { Characteristic } \\
\text { s }\end{array}$} & & $\begin{array}{c}5.4 \\
\text { fibres } / \mathrm{m}^{3}\end{array}$ & $\begin{array}{l}0.4-59.4 \\
\text { fibres } / \mathrm{m}^{3}\end{array}$ & $\leq 3250$ & \multirow[b]{2}{*}{ fibres } & \multirow{2}{*}{$\begin{array}{c}\text { PP, PA, copolymers of } \\
\text { PP and PE }\end{array}$} & \multirow{2}{*}{$\begin{array}{l}\text { (Dris et } \\
\text { al., } \\
\text { 2017) }\end{array}$} \\
\hline $\begin{array}{c}\text { Indoor } \\
\text { dust }\end{array}$ & & & & $\begin{array}{l}190-670 \\
\text { fibres } / \mathrm{mg}\end{array}$ & $\begin{array}{c}4650- \\
4850\end{array}$ & & & \\
\hline $\begin{array}{c}\text { Indoor } \\
\text { air }\end{array}$ & $\begin{array}{c}\text { Occurrence + } \\
\text { Contaminant } \\
\text { load }+ \\
\text { Characteristic }\end{array}$ & $\begin{array}{c}9.3 \pm 5.8 \\
\text { particles/ } \\
\mathrm{m}^{3}\end{array}$ & & $\begin{array}{c}1.7-1.62 \\
\text { particles } / \mathrm{m}^{3}\end{array}$ & - & $\begin{array}{c}\text { Fibres, } \\
\text { fragments }\end{array}$ & $\begin{array}{c}\text { PES, PE, PA, PP, PS, } \\
\text { acrylic, PUR, PVA, } \\
\text { EVA, EP, }\end{array}$ & $\begin{array}{l}\text { (Vianel } \\
\text { lo et } \\
\text { al., } \\
2019 \text { ) }\end{array}$ \\
\hline
\end{tabular}

PET: polyethylene terephthalate, PE: polyethylene, PES: polyester, PAN: polyacrylonitrile, PAA: poly(N-methyl acrylamide), RY: rayon, EVA: ethylene vinyl acetate, EP: epoxy resin; ALK: alkyd resin; PEP: poly (ethylene: propylene); PC: Polycarbonate, PEI: polyethyleneimine 
TABLE 7: Percent Abundance of Microplastics Morphotype

\begin{tabular}{|c|c|c|c|c|c|c|c|}
\hline \multicolumn{8}{|c|}{ Shapes (\%) } \\
\hline Film & Fibre & Granule & Pellet & Spherule & Fragment & Foam & Ref \\
\hline- & 33.5 & 65.9 & 2 & 9 & - & - & $\begin{array}{c}\text { (Dehghani et al., } \\
\text { 2017) }\end{array}$ \\
\hline 14 & - & - & - & 74 & - & - & $\begin{array}{c}\text { (Abbasi et al., } \\
\text { 2019) }\end{array}$ \\
\hline- & 75.87 & - & - & - & 17.5 & - & $\begin{array}{c}\text { (Abbasi et al., } \\
\text { 2017) }\end{array}$ \\
\hline & 13 & & & & 87 & & $\begin{array}{c}\text { (Vianello et al., } \\
\text { 2019) }\end{array}$ \\
\hline & 67 & 3 & & & 30 & & (Liu et al., 2019c) \\
\hline & $88^{\mathrm{a}}$ & & & & & & (Liu et al., 2019a) \\
\hline & $73.7^{b}$ & & & & & & \\
\hline
\end{tabular}


TABLE 8: Overview of Atmospheric Particles/ Fibres Reported in Some Reviewed Microplastic Studies

\begin{tabular}{c|cccccc}
\hline \multicolumn{1}{c}{ Matrix } & \multicolumn{4}{c}{ \% Composition } \\
\hline \multicolumn{1}{c}{ Number of particles analysed } & Natural & Synthetic & Artificial & Copolymers & Ref \\
\hline Indoor environment* & 28 & 67 & 33 & - & - & (Dris et al., 2017) \\
\hline Atmospheric fallout* & $\mathrm{NS}$ & 73 & 27 & - & - & (Cai et al., 2017) \\
\hline Atmospheric fallout* & 24 & 50 & 17 & 21 & 12 & (Dris et al., 2016) \\
\hline Suspended air & $\mathrm{NS}$ & 46 & 54 & & (Liu et al., 2019c) \\
\hline Atmospheric fallout* & 1100 & 97.7 & 2.3 & - & (Stanton et al., 2019) \\
\hline Indoor air & $\mathrm{NS}$ & 95 & 4 & - & - & (Vianello et al., 2019) \\
\hline
\end{tabular}




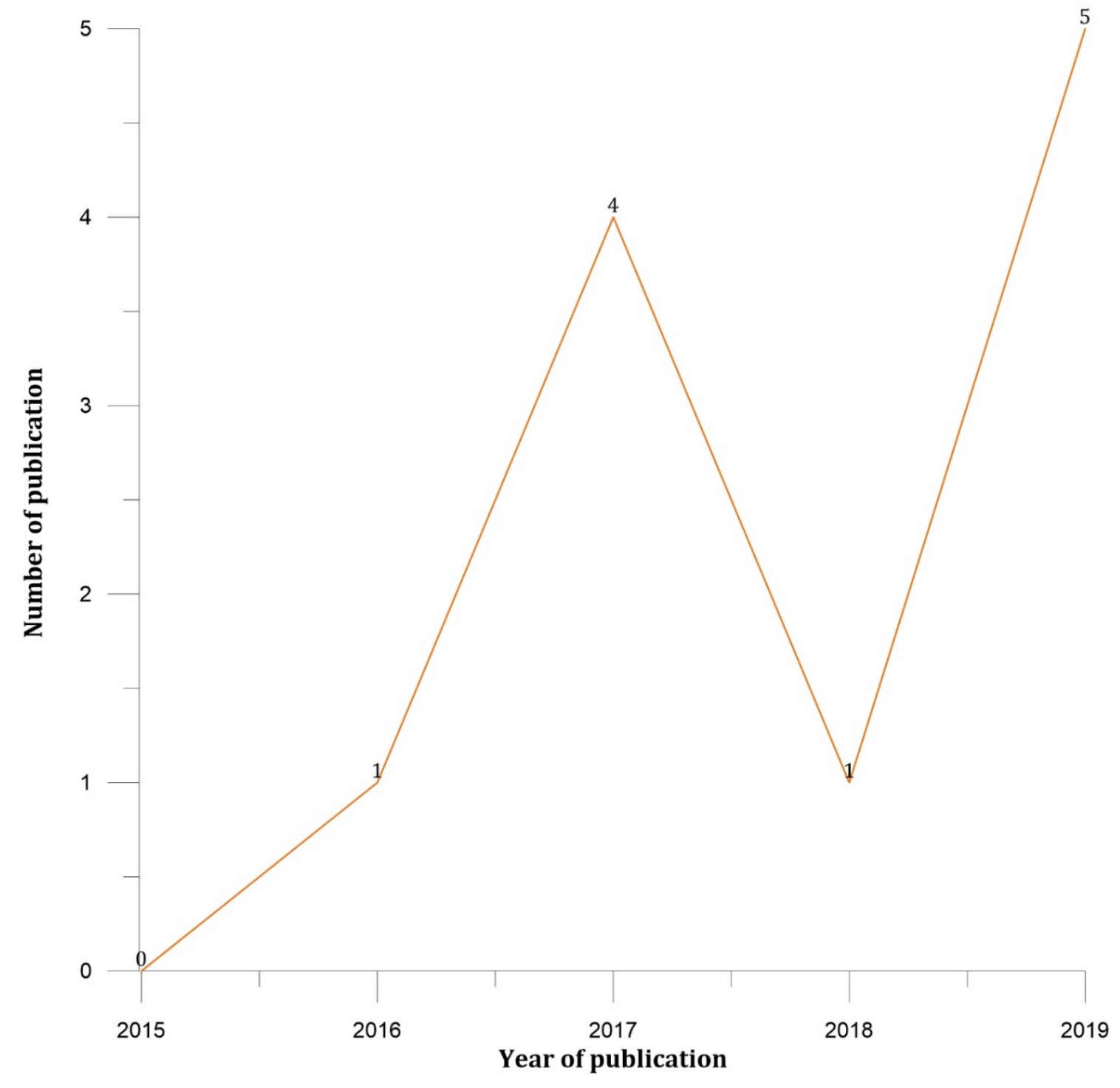

FIGURE 1: Trend in the number of atmospheric microplastic studies 


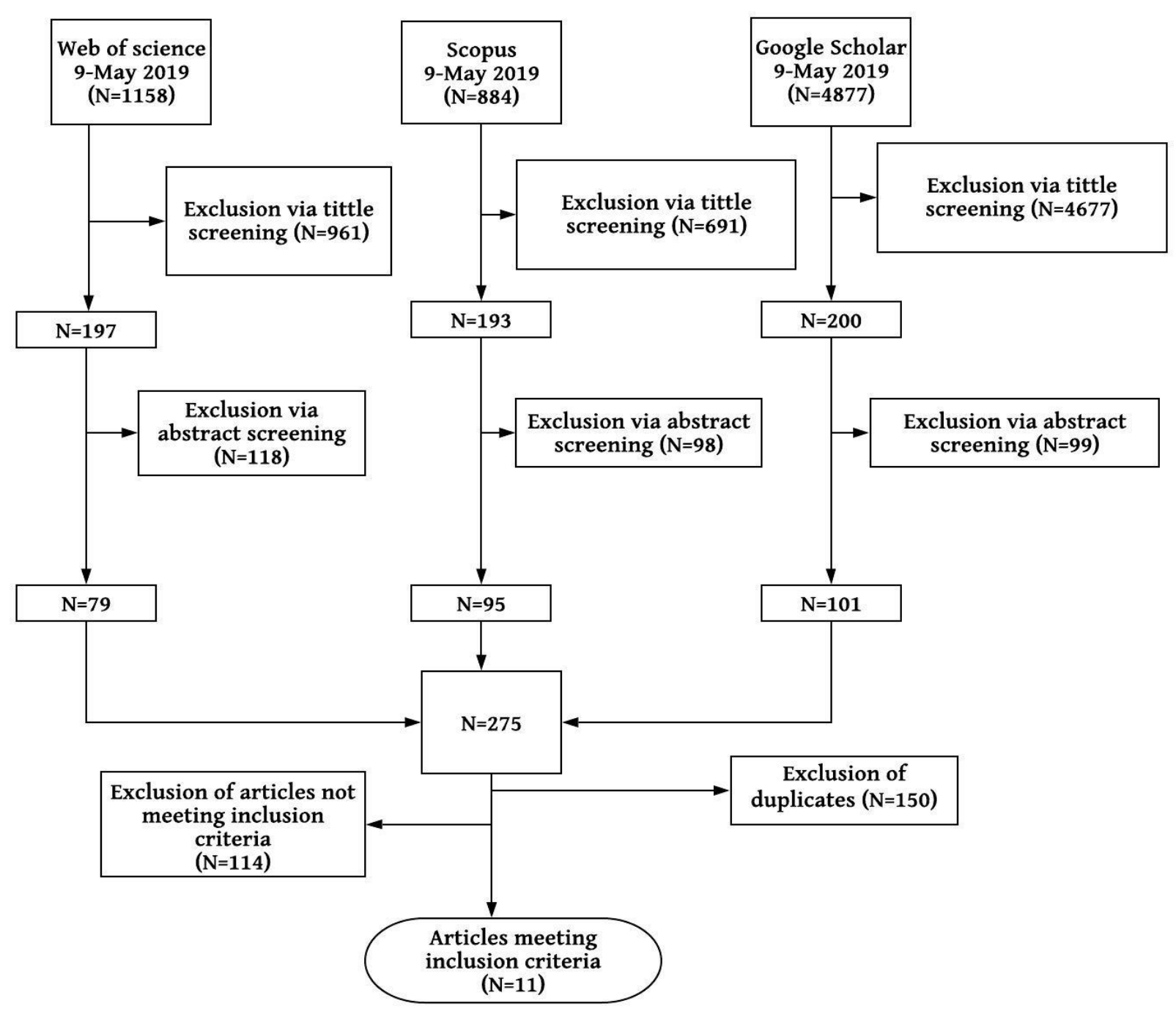

*step is not always necessary

Figure 2: Flow diagram of the search strategy used for this review 


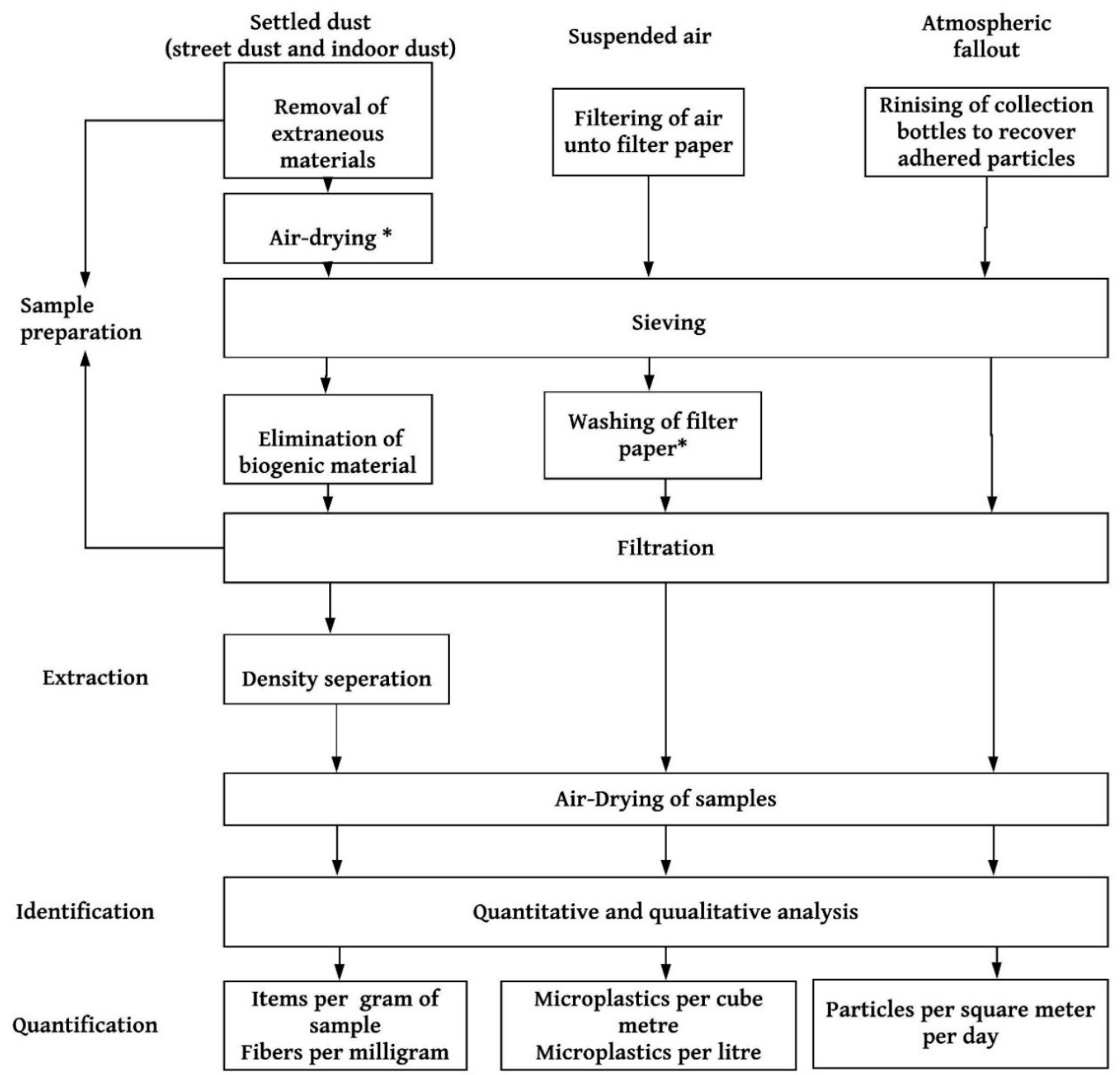

FIGURE 3: Sample preparation step for microplastics in (1) settled dust (street dust and indoor) (Abbasi et al., 2017, Abbasi et al., 2019, Dehghani et al., 2017, Dris et al., 2017, Liu et al., 2019a), (2) suspended and atmospheric fallout samples (Abbasi et al., 2019, Cai et al., 2017, Dris et al., 2017, Dris et al., 2016, Liu et al., 2019c, Stanton et al., 2019) 


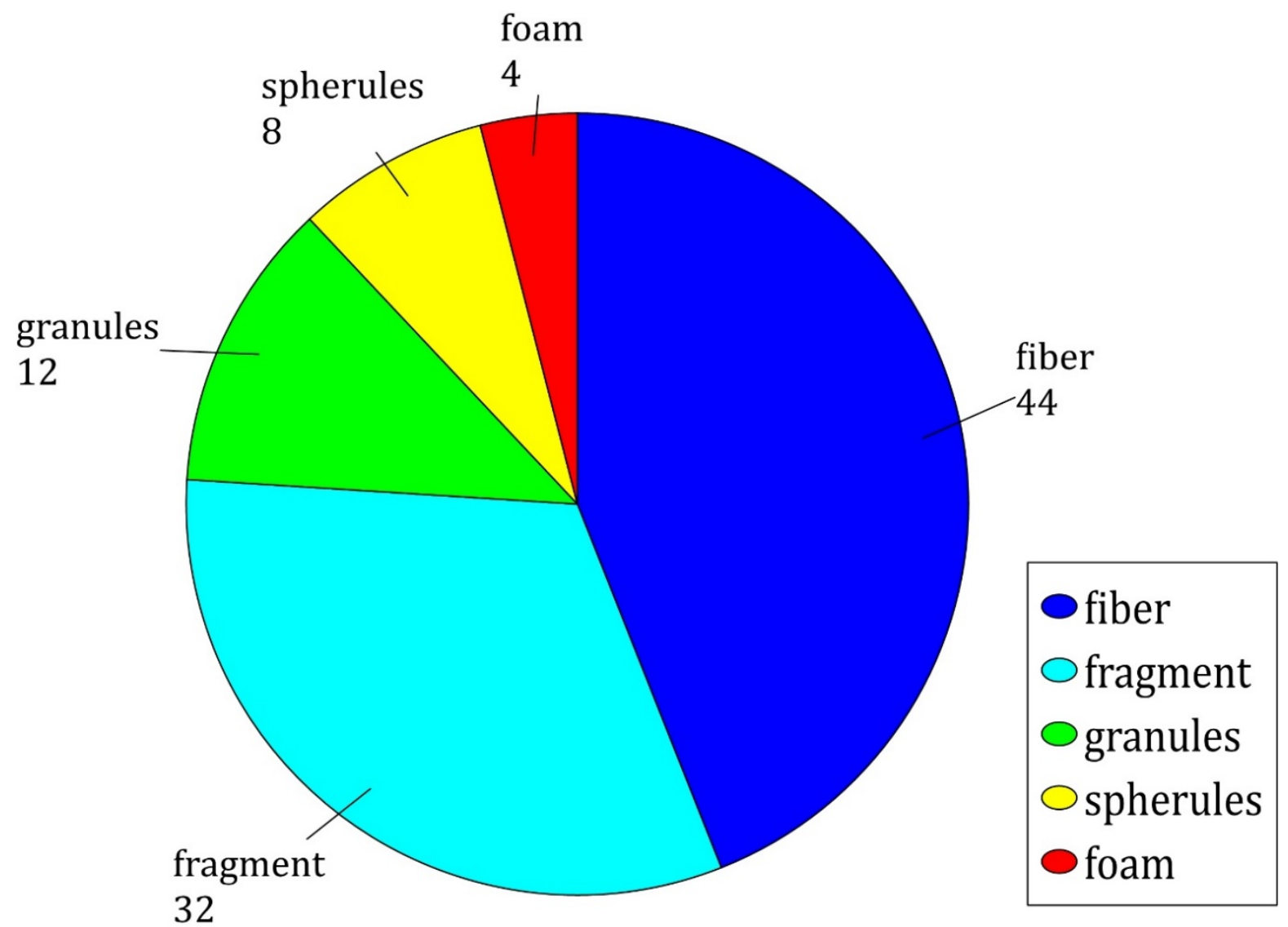

FIGURE 4: Frequency of morphotypes observed from the reviewed literature. 


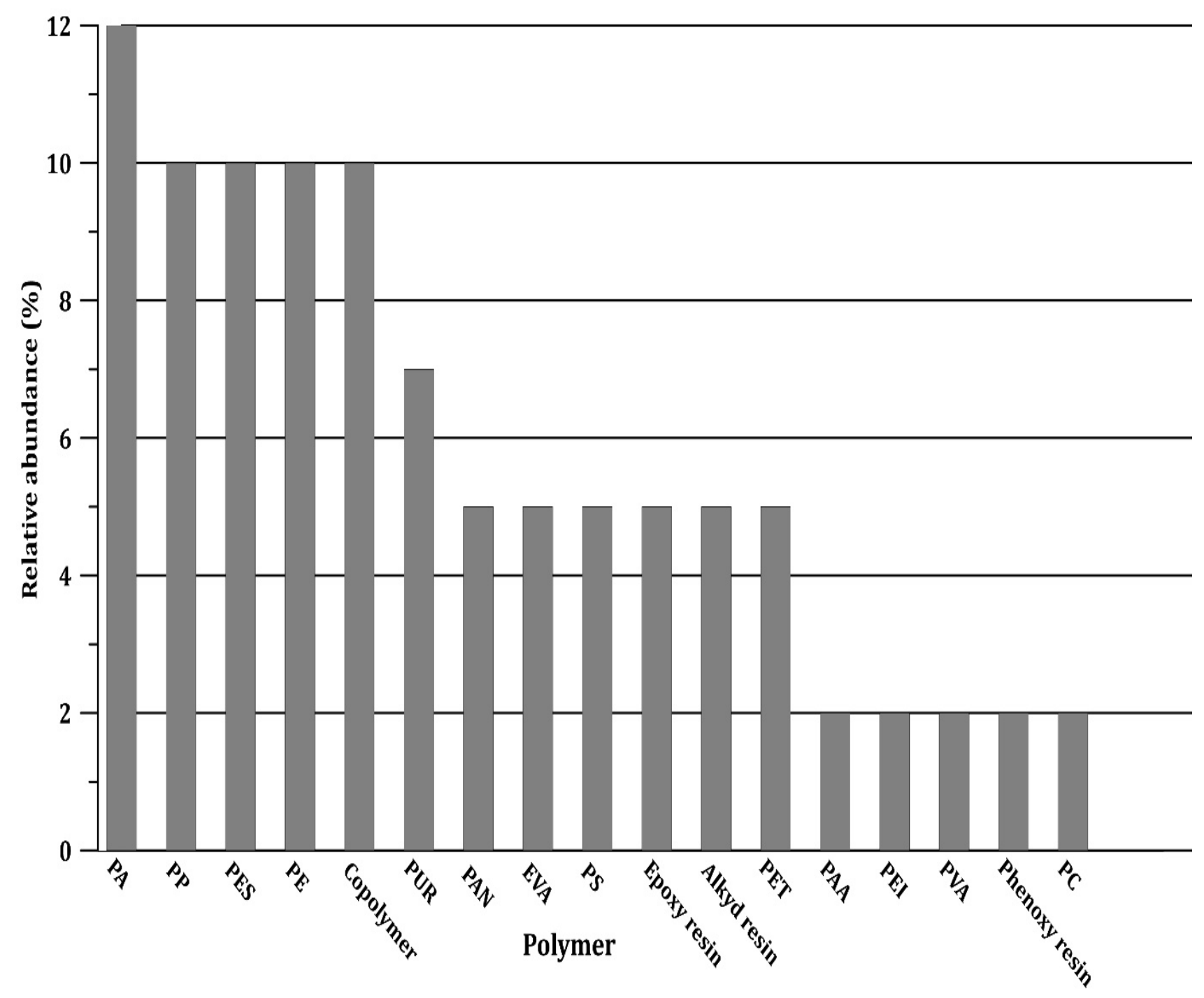

Figure 5: Relative abundance in percent of polymer types of microplastics identified in the atmosphere. 